\title{
Working
}

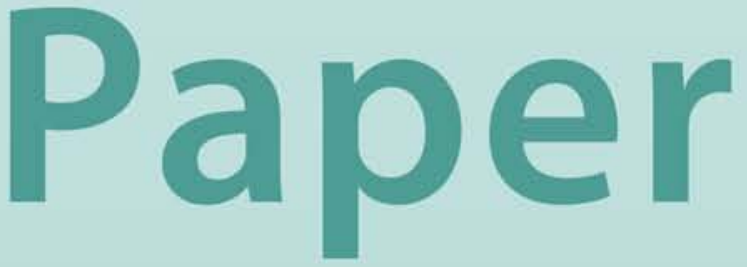


Coping with Capital Inflows: Experiences of Selected European Countries

İnci Ötker-Robe, Zbigniew Polański, Barry Topf, and David Vávra 


\title{
IMF Working Paper
}

Monetary and Capital Markets Department

\section{Coping with Capital Inflows: Experiences of Selected European Countries}

\author{
Prepared by \\ İnci Ötker-Robe, Zbigniew Polański, Barry Topf, and David Vávra ${ }^{1}$ \\ Authorized for distribution by Daniel Hardy
}

July 2007

\begin{abstract}
This Working Paper should not be reported as representing the views of the IMF. The views expressed in this Working Paper are those of the author(s) and do not necessarily represent those of the IMF or IMF policy. Working Papers describe research in progress by the author(s) and are published to elicit comments and to further debate.

This paper reviews the experiences of a number of European countries in coping with capital inflows. It describes the nature of the inflows, their implications for macroeconomic and financial stability, and the policy responses used to cope with them. The experiences suggest that as countries become more integrated with international financial markets, there is little room to regulate capital flows effectively. The most effective ways to deal with capital inflows would be to deepen the financial markets, strengthen financial system supervision and regulation, where needed, and improve the capacity to design and implement sound macroeconomic and financial sector policies. These actions will help increase the absorption capacity and resilience of the economies and financial systems to the risks associated with the inflows.

JEL Classification Numbers: $\quad$ E42, E43, E52, F21, F31, F32, F36, G21

Keywords: Capital inflows, capital markets integration, inflation targeting, policy responses

Author’s E-Mail Address: $\quad$ iotker@imf.org, barrytp@bankisrael.gov.il, zbigniew.polanski@mail.nbp.pl, dvavra@imf.org

\footnotetext{
${ }^{1}$ International Monetary Fund, the National Bank of Poland, the Bank of Israel, and formerly the Czech National Bank, respectively. Comments from Martins Bitans, Nada Choueiri, Costas Christou, Martin Cihak, Karl Driessen, Robert Feldman, Lorenzo Giorgianni, Gavin Gray, Robert Hagemann, Daniel Hardy, Alexander Hoffmaister, Han Herderschee, Wes McGrew, Andre Meier, Ashoka Mody, David Moore, Ceyla Pazarbasioglu, Stanislav Polak, Piotr Szpunar, Chris Towe, Rachel van Elkan, Andrew Tiffin, and Dalia Treigiene, and able research assistance from Yulia Makarova and Nada Oulidi are greatly appreciated.
} 
Contents

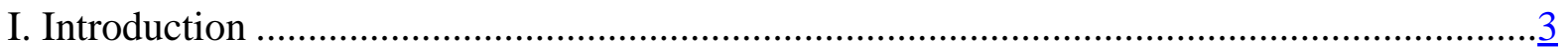

II. Stylized Features and Determinants of the Capital Inflows .............................................

III. Macroeconomic and Financial Impact of the Inflows …............................................

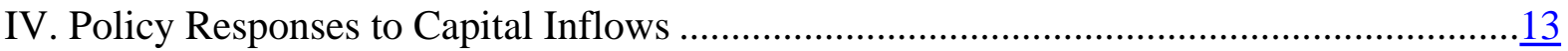

A. Policy Responses During Periods of Exchange Rate Targeting ............................13

B. Policy Responses Under More Flexible Exchange Rates and

Inflation Targeting ................................................................................... 15

C. Challenges in Responding to Inflows Imposed by EU Integration .........................17

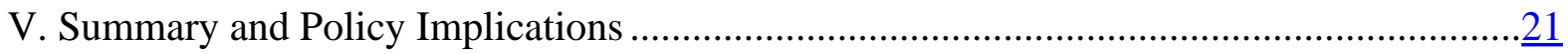

Tables

1. Common Factors Significant in Attracting the Flows .................................................. $\underline{8}$

2. Macroeconomic and Financial Sector Implications of the Capital Inflows.......................... $\underline{9}$

3. Selected European Countries: Policy Responses to the Inflows, 1993_Present.................18

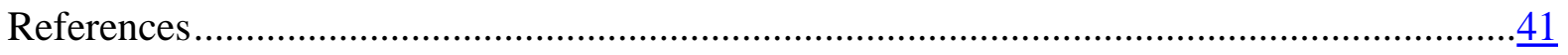

Figures

1. Selected Countries: Gross Capital Inflows, 1994-2005 ...................................................

2. Selected European Countries: Current Account Balance and Credit Growth .....................11

Boxes

1. Responses to Credit Growth and Capital Inflows: Croatia and Romania...........................20

Appendixes

I. Factors Motivating Capital Inflows, Their Implications, and Policy Responses ................24

II. Experiences of Israel and Poland with Capital Account Liberalization..............................

Appendix Tables

4. Selected European Countries: Factors Underlying the Capital Inflows .............................24

5. Selected European Countries: Macroeconomic and Financial Implications of Inflows.......27

6. Policy Responses to the Capital Inflows in the Selected European Countries .................... 


\section{INTRODUCTION}

Many European emerging market economies have experienced large-and sometimes disruptive-capital flows in recent years. While foreign direct investment (FDI) initially made up the bulk of the inflows, portfolio inflows, especially into debt securities, and inflows into domestic banking systems have gained importance over time. Although the inflows played an important role in the economic and financial development of the economies, they also complicated macroeconomic management, putting a high premium on the consistency of macroeconomic policies and the presence of adequate systems for regulation and supervision of the institutions intermediating them.

These capital inflows have been taking place in the context of liberalization of the previously closed economies and their gradual integration with international capital markets. In particular, the inflows into the central and eastern European countries have taken place in the context of their gradual integration with the EU and other international economic institutions, such as the OECD. These institutional changes have not only been important in stimulating the capital flows into these economies, but have also shaped the policy responses to the complications that the inflows brought for macroeconomic and financial stability. Greater exchange rate flexibility that some of the countries adopted, partly in response to the inflows, and the choice of inflation targeting (IT) as the new monetary policy framework have added a different dimension to the challenges faced in responding to inflows.

The objective of this paper is to present the experiences of 11 European countries $^{2}$ with $^{2}$ a view to provide lessons for countries experiencing large capital inflows. The paper reviews the nature of the capital flows into these countries, their macroeconomic and financial stability implications, and the authorities' policy responses to cope with them. It shows that the general response to the inflows has been somewhat different in these countries compared with the previous episodes of heavy capital inflows elsewhere. Compared with the past episodes of heavy capital inflows (e.g., Brazil (1993-97), Chile (1991-98), Colombia (1993-98), Malaysia (1994), and Thailand (1995-97)), ${ }^{3}$ the sample countries have relied less on the more conventional tools of capital inflow management, but more on measures that help increase the capacity to absorb, and enhance the resilience to the risks associated with, the inflows.

\section{STYLIZED FEATURES AND DETERMINANTS OF THE CAPITAL INFLOWS}

The nature of the capital inflows has evolved over time. For the most part, the inflows were persistent and large (Figure 1), averaging in gross terms at about 9.6 percent of GDP in the sample countries during 1994-2005, and ranging from 3.4 percent of GDP in Turkey to 17 percent of GDP in Estonia and Latvia. At the same time, the maturity structure of the inflows has been volatile, and several countries have experienced brief episodes of capital

\footnotetext{
${ }^{2}$ Bulgaria, Croatia, the Czech Republic, Estonia, Hungary, Israel, Latvia, Lithuania, Poland, Romania, and Turkey.

${ }^{3}$ See Ariyoshi and others (2000) and the literature cited therein for a description of these experiences.
} 
Figure 1. Selected Countries: Gross Capital Inflows, 1994-2005

(in percent of GDP)
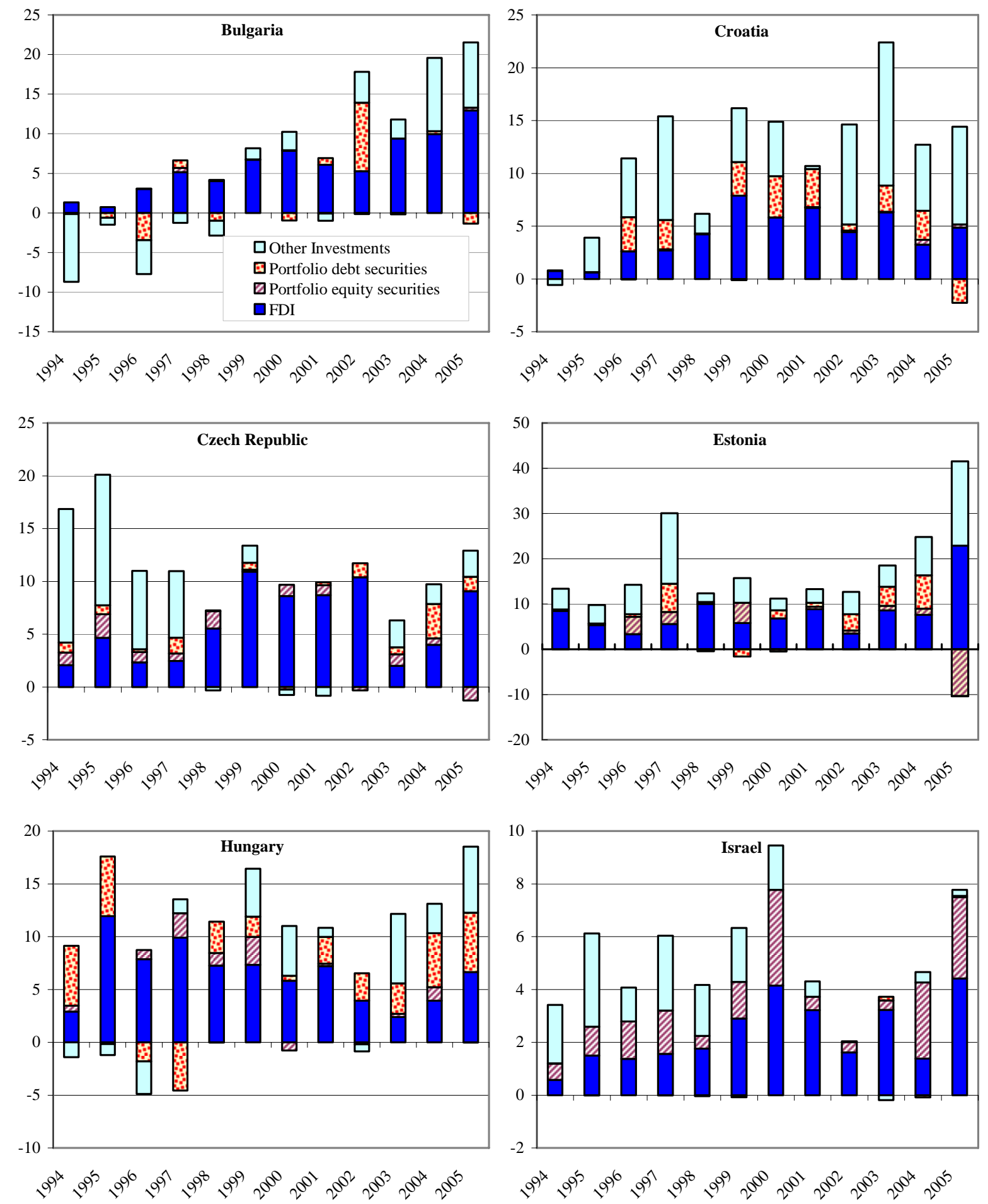

Source: IFS and author's calculations 
Figure 1 (Concluded). Selected European Countries: Gross Capital Inflows, 1994-2005 (in percent of GDP)
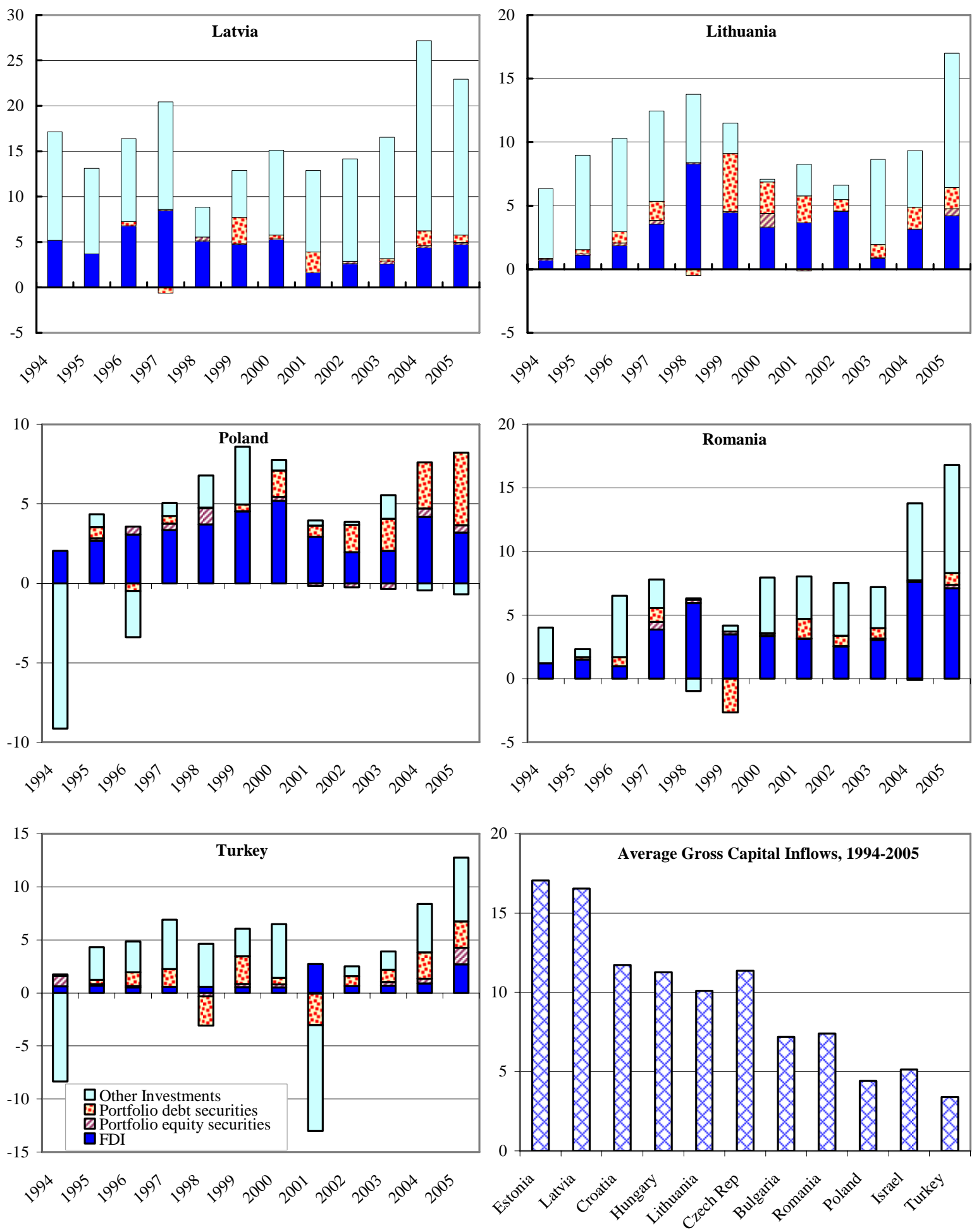

Source: IFS and authors' calculations

1/ For Latvia, 1994-1995 portfolio debt/equity securities data are unavailable and for Lithuania, 1994 portfolio debt securities data are unavailable. 
flow reversals, particularly following periods of inflows with a significant short-term component, in some cases also into the banking system. Reversals were particularly marked in the Baltic's in the late 1990s, the Czech Republic (1997 and 1998), Croatia (1998), and Turkey (2001).

The composition of the inflows has also changed over time. Initially, FDI made up the bulk of the inflows in Bulgaria, Hungary, and Poland, with the role of portfolio investment gaining importance over time. In Israel, foreign currency credits were at first the most important, but FDI became the largest component subsequently. Similarly in the Czech Republic, other investment dominated the inflows until the 1997 currency turmoil, after which FDI had the generally most significant share. ${ }^{4}$ The importance of portfolio inflows rose at later stages, along with the development of the capital markets. Such inflows were channeled primarily into debt securities, and only subsequently, and to a lesser extent, into equity securities (most clearly in Israel). There has been a marked rise in inflows to the banking system (initially as FDI into the financial sector, followed by bank financing-under “other investment”) in Bulgaria, Croatia, Hungary, Romania, and Turkey; ${ }^{5}$ in the Baltics, such inflows have continued to have the largest share.

Country-specific factors played a dominant role in stimulating the inflows. For the EU accession countries, prospects for investment returns have been boosted by lower risk premia associated with macroeconomic stabilization, improved policy credibility, and prospects linked to EU-related structural reforms (see Table 1 and Table 4). Better economic prospects and policy credibility were also important in Israel. High domestic interest rates attracted return-sensitive inflows, especially when combined with stable exchange rates. Large scale privatizations, regulatory improvements and financial deregulation, foreign debt restructuring in the early to mid-1990s, as well as EU transfers in the accession countries also played a role in attracting the inflows. ${ }^{6}$ More advanced capital markets led to larger inflows in Bulgaria, Hungary, and Poland, while in the Czech Republic inflows made up for poorly developed domestic markets that were unable to provide funds.

In addition to country-specific factors, global conditions and trends were also important in directing capital flows to these economies. Capital inflows tended to be associated with declining interest rates in the industrialized countries (compared to domestic interest rates) and with increased global liquidity (see, e.g., IMF, 2005). Exogenous geopolitical events led to a decline in Israel's risk premium. In Turkey, inflows into bond markets have also been stimulated by the hedging needs of foreign issuers of new Turkish lira papers following the

\footnotetext{
${ }^{4}$ In the early 2000s, the share of other investments (including, e.g., a significant fall in the short term assets of commercial banks abroad), as well as purchases of domestic bonds by nonresidents were also non-negligible.

5 There were no net inflows through the banking system in Bulgaria in 2005, largely as a result of the credit limits that were introduced early that year.

${ }^{6}$ In the Czech Republic, Hungary, Poland, and Romania, the liberalization of capital flows was a key commitment in the context of EU accession and OECD membership.
} 
redenomination of the currency. ${ }^{7}$ The impact of regional financial crises varied in line with the vulnerabilities of the country and its exposure to possible contagion effects. Contagion effects led to a reversal of inflows from the Czech Republic in 1997 and reduced inflows into Croatia in 1998.

For a number of the countries, an additional factor in recent years has been the rapid growth of bank credit to the private sector, funded by bank borrowing from abroad (the Baltic's, Bulgaria, Croatia, Hungary, Romania, and lately Turkey). The increase in inflows through the banking system has been facilitated in many cases by the arrival of foreign banks that now dominate the banking systems. ${ }^{8}$ These banks have been very active in stimulating the rapid expansion of bank lending with the aim of gaining market share, and have turned to borrowing from abroad for funding, as the pace of credit growth exceeded that of the banks' deposit base (see, e.g., Hilbers, Ötker-Robe, Pazarbasioglu, and Johnsen, 2005).

\section{MACROECONOMIC AND FINANCIAL IMPACT OF THE INFLOWS}

\section{Capital inflows (especially with a large FDI component) have brought substantial macroeconomic and financial benefits. The inflows expanded the available resources for funding productive investments and privatization and for raising export capacity (Bulgaria, the Czech Republic, Hungary, Poland, and Romania-Table 2), and helped finance current account deficits (the Baltic’s, Bulgaria, the Czech Republic, Hungary, Poland, Turkey). They contributed to the development of domestic financial markets and the efficiency of banking systems (the Baltic’s, Bulgaria, Croatia, the Czech Republic, Poland, Turkey). Foreign participation in domestic government securities markets contributed to liquidity of secondary markets and greater sophistication of financial services (Hungary and Poland). FDI helped transfer managerial and technological skills and strengthen domestic institutions. ${ }^{9}$ For the EU accession countries, capital inflows were a mutually reinforcing factor in the process of integration into the EU.}

\footnotetext{
${ }^{7}$ See Kapteyn, Keller, and McGettigan (2005). Some issuers, merely issued the YTL bonds and onlent the proceeds in Turkey for projects - a natural currency hedge. Issuing YTL bonds, other private foreign issuers used the proceeds to buy (higher yielding) domestic public debt instruments as a currency hedge, thereby prompting capital inflows. This type of hedging is associated with international investors who may have appetite for exposure to the YTL and the higher local rates in Turkey but may face restrictions (e.g., to invest only in investment grade credit), or simply shy away from the transaction costs of buying Turkish paper directly. For these investors, a foreign bank may issue a 5 or 10 year bond denominated in YTL and demand or buy a similar bond issued by the Turkish Treasury to cover the YTL liability this creates on the balance sheet.

${ }^{8}$ Foreign banks hold an average of 80 percent of domestic banking system assets, except in Turkey, where the share of foreign-controlled banks continues to be small (about $1 / 4$ of total assets).

${ }^{9}$ FDI into the banking and financial sectors in Croatia and Poland and functioning of branches of foreign banks in the Czech Republic brought increased efficiency and managerial skills, and contributed to the development of interbank FX and bank-client markets, thereby providing an important stabilizing element for managing FX risks (e.g., during the currency crisis). In the Baltic’s, subsidiaries of foreign banks have benefited from knowledge transfer as foreign parent banks have enforced credit management techniques on their subsidiaries similar to those in their home institutions (see e.g., Adahl, 2002, and Schipke, and others, 2004).
} 
Table 1. Common Factors Significant in Attracting the Flows

\begin{tabular}{|c|c|c|c|c|c|c|c|c|}
\hline & \multicolumn{5}{|c|}{ Pull } & \multicolumn{3}{|c|}{ Push } \\
\hline & $\begin{array}{c}\text { High } \\
\text { domestic } \\
\text { interest rates } \\
\text { w/exchange } \\
\text { rate stability }\end{array}$ & $\begin{array}{l}\text { Privatization } \\
\text { projects }\end{array}$ & $\begin{array}{c}\text { Institutional } \\
\text { reforms and } \\
\text { integration into } \\
\text { supranational } \\
\text { institutions }\end{array}$ & $\begin{array}{c}\text { Improved } \\
\text { macroeconomic } \\
\text { performance and } \\
\text { prospects }\end{array}$ & $\begin{array}{l}\text { Credible } \\
\text { monetary and } \\
\text { fiscal policies }\end{array}$ & $\begin{array}{l}\text { Arrival of foreign } \\
\text { banks financing } \\
\text { credit growth }\end{array}$ & $\begin{array}{l}\text { Decline in } \\
\text { world interest } \\
\text { rates }\end{array}$ & $\begin{array}{l}\text { Institutional } \\
\text { restructuring } \\
\text { of foreign debt }\end{array}$ \\
\hline $\begin{array}{l}\text { Bulgaria } \\
\text { (1997-present) }\end{array}$ & Yes & Yes & Yes & Yes & Yes & Yes & Yes & \\
\hline $\begin{array}{l}\text { Croatia } \\
\text { (1993-present) }\end{array}$ & Yes & & Yes & Yes & Yes & Yes & Yes & Yes \\
\hline $\begin{array}{l}\text { Czech R. } \\
(1993-2004)\end{array}$ & Yes & Yes & Yes & Yes & Yes $^{1}$ & Yes & Yes & \\
\hline $\begin{array}{l}\text { Estonia } \\
\text { (2000-present) }\end{array}$ & & Yes & Yes & Yes & Yes & Yes & Yes & \\
\hline $\begin{array}{l}\text { Hungary } \\
\text { (1995-present) }\end{array}$ & Yes & & Yes & Yes & Yes $^{2}$ & Yes & Yes & \\
\hline $\begin{array}{l}\text { Israel } \\
(1988-98)\end{array}$ & Yes & & & Yes & Yes & & & \\
\hline $\begin{array}{l}\text { Latvia } \\
\text { (1998-present) }\end{array}$ & Yes & & Yes & Yes & Yes & Yes & Yes & \\
\hline $\begin{array}{l}\text { Lithuania } \\
\text { (1994-98 and } \\
\text { 2002-present) }\end{array}$ & Yes & Yes & Yes & Yes & Yes & Yes & Yes & \\
\hline $\begin{array}{l}\text { Poland } \\
(1991-2005)\end{array}$ & Yes & Yes & Yes & Yes & Yes & & Yes & Yes \\
\hline $\begin{array}{l}\text { Romania } \\
\text { (2004-present) }\end{array}$ & Yes & Yes & Yes & Yes & & Yes & Yes & \\
\hline $\begin{array}{l}\text { Turkey } \\
\text { (2003-present) }\end{array}$ & Yes & Yes & Yes & Yes & Yes & Yes & Yes & \\
\hline
\end{tabular}

Source: Table 4 in Appendix I.

${ }^{1}$ After 1998.

${ }^{2}$ After a narrowing of the band in the mid-1990s. 
Table 2. Macroeconomic and Financial Sector Implications of the Capital Inflows

\begin{tabular}{|c|c|c|c|c|c|c|c|c|c|c|c|}
\hline & $\begin{array}{c}\text { Bulgaria } \\
(1997- \\
\text { present })\end{array}$ & $\begin{array}{l}\text { Croatia } \\
(1993- \\
\text { present })\end{array}$ & $\begin{array}{l}\text { Czech R. } \\
(1993-2004)\end{array}$ & $\begin{array}{l}\text { Estonia } \\
(2000- \\
\text { present) }\end{array}$ & $\begin{array}{c}\text { Hungary } \\
(1995- \\
\text { present) }\end{array}$ & $\begin{array}{c}\text { Israel } \\
(1988- \\
1998) \\
\end{array}$ & $\begin{array}{l}\text { Latvia } \\
(1998- \\
\text { present) }\end{array}$ & $\begin{array}{l}\text { Lithuania } \\
\text { (1994-98, } \\
\text { 2002-pres.) }\end{array}$ & $\begin{array}{c}\text { Poland } \\
(1991-2005)\end{array}$ & $\begin{array}{l}\text { Romania } \\
\text { (2004- } \\
\text { present) }\end{array}$ & $\begin{array}{l}\text { Turkey } \\
\text { (2003- } \\
\text { present) }\end{array}$ \\
\hline \multicolumn{12}{|c|}{ Macroeconomic Impact } \\
\hline $\begin{array}{l}\text { Improvement in productivity and } \\
\text { competitiveness (supply side effects) }\end{array}$ & Yes & & Yes & Yes & & & & & Yes & Yes & Yes \\
\hline Financing of current account deficits & Yes & Yes & Yes & Yes & Yes & & Yes & Yes & Yes & Yes & Yes \\
\hline $\begin{array}{l}\text { Macroeconomic overheating, including inflation } \\
\text { pressures and worsening CA under fixed } \\
\text { exchange rate arrangements, putting a premium } \\
\text { on appropriate policy mix }\end{array}$ & Yes & Yes & Yes & Yes & Yes & Yes $^{1}$ & Yes & Yes & Yes & Yes & \\
\hline $\begin{array}{l}\text { Complicating monetary policy management by } \\
\text { exposing inconsistencies in simultaneously } \\
\text { achieving low inflation and competitiveness } \\
\text { through exchange rate (nominal/real) targeting }\end{array}$ & & Yes & Yes & & Yes & Yes & & & Yes & Yes & \\
\hline $\begin{array}{l}\text { Financial market volatility jeopardizing a fixed } \\
\text { exchange rate arrangement }\end{array}$ & & Yes & Yes & & & & Yes & & & & \\
\hline $\begin{array}{l}\text { Threats of undershooting inflation objectives } \\
\text { under a free float }\end{array}$ & & & Yes & & & Yes & & & Yes & & \\
\hline Threats to competitiveness under a free float & & & Yes & & & & & & Yes & Yes & Yes \\
\hline $\begin{array}{l}\text { Rise in the external debt of banks and } \\
\text { corporations }\end{array}$ & Yes & Yes & & Yes & & & Yes & Yes & Yes & & Yes \\
\hline $\begin{array}{l}\text { Fueling credit growth (hence agg. demand) and } \\
\text { rising external imbalances }\end{array}$ & Yes & Yes & & Yes & Yes & & Yes & Yes & & Yes & Yes \\
\hline \multicolumn{12}{|c|}{ Financial Sector Impact } \\
\hline $\begin{array}{l}\text { Exposure of the banking and corporate sector to } \\
\text { FX risks (direct and indirect), with potential } \\
\text { risks for financial sector stability }\end{array}$ & Yes & Yes & & Yes & Yes & & Yes & Yes & Yes $^{2}$ & Yes & Yes \\
\hline $\begin{array}{l}\text { Contribution to a rapid credit growth, raising } \\
\text { sustainability concerns by exposing banks to } \\
\text { market and credit risks }\end{array}$ & Yes & Yes & & Yes & Yes & & Yes & Yes & Yes $^{1}$ & Yes & Yes \\
\hline $\begin{array}{l}\text { Contribution to development of financial and } \\
\text { FX markets, including through rising } \\
\text { transaction volumes, privatization of state banks } \\
\text { or operations of foreign institutions }\end{array}$ & Yes & Yes & Yes & Yes & & Yes & Yes & Yes & $\mathrm{Yes}^{3}$ & & \\
\hline
\end{tabular}

Source: Table 5 in Appendix I.

${ }^{1}$ Before moving to flexible exchange rates.

${ }^{2}$ In 1990s, later the banking sector became resilient to these threats.

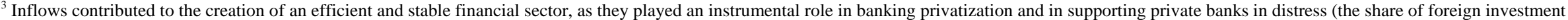

in banks' capital reached 18.1 percent in 1995, 53.8 percent in 2000 and more than 60 percent since 2002). 
At the same time, the size, nature, and persistence of the inflows complicated macroeconomic policy implementation and contributed to macroeconomic vulnerabilities. Policy tensions often surfaced when multiple policy objectives were pursued (inflation and exchange rate targets) while opening the capital account - the "impossible trinity dilemma" (the Baltics, Hungary, the Czech Republic, and Israel until 1997, Poland until 1999, and Romania until 2005). Large and persistent inflows put appreciation pressures on the domestic currencies and led to periods of monetary expansion when appreciation pressures were resisted (Croatia, the Czech Republic, Poland during 1994-98), and/or to a slowdown in the process of disinflation with greater current account deficits (the Baltic's, Hungary, Poland in the late 1990s, and Romania). Where allowed, the appreciation helped disinflation, though usually where the latter was falling from high levels (Hungary, Poland, Romania, Turkey). In a number of cases, significant appreciation under floating exchange rates also raised concerns for instance about undershooting the official inflation targets (the Czech Republic, Israel, and Poland) and loss of competitiveness (the Czech Republic, Poland, Romania, and Turkey).

The inflows have also raised policy challenges associated with a rapid expansion of banking sector credit financed increasingly by the inflows. The rapid growth of credit to the private sector in the Baltics, Bulgaria, Croatia, Hungary, and Romania has contributed to the widening of current account deficits (Figure 2), by stimulating aggregate demand through higher imports and consumption. Growing external indebtedness of the private sector has been a significant concern in the Baltics and Turkey, as well as in Croatia where banks borrowed to fund lending growth and corporations switched to direct borrowing in response to the restrictions imposed on the banking system. In the Baltic's, target dates for euro adoption were delayed given the rising inflation pressures that risk meeting the Maastricht criteria. The need to manage the macroeconomic impact of credit expansion induced the authorities to resort to more direct measures where indirect monetary instruments have been limited or ineffective in the presence of high euroization (e.g., administrative measures in Bulgaria and Croatia, and reserve requirements in both countries as well as in the Baltics).

The rapid credit growth fueled by the capital inflows have also given rise to potential risks to financial sector stability (the Baltics, Bulgaria, Croatia, Hungary, Romania, and Turkey). Financing the loans increasingly from abroad ${ }^{10}$ created balance sheet mismatches as banks lent the private sector in domestic currency the foreign currency funds borrowed from abroad. Even where FX exposures have remained within permitted limits, the large FXlinked component of the loans to borrowers with limited FX income or hedging have made banks increasingly more exposed to FX-related credit risks. ${ }^{11}$ Some deterioration in lending standards has also been observed as banks competed for market share (Bulgaria, Croatia,

\footnotetext{
${ }^{10}$ In fact, there has been a significant deterioration in banks' net foreign asset positions since the early 2000s (see Hilbers, Ötker-Robe, Pazarbasioglu, and Johnsen, 2005).

${ }^{11}$ The real growth of banking sector credit ranged from 16-45 percent in the Baltic's, Bulgaria, Croatia, Hungary, and Romania during 2002-2005, with a significant FX component, ranging from 40-80 percent of total loans (Enoch and Ötker-Robe, 2007). In Turkey, there has been a significant increase in consumer loans in recent years and banks are exposed to indirect FX risks through their customers.
} 
Figure 2. Selected European Countries: Current Account Balance and Credit Growth (in percent)
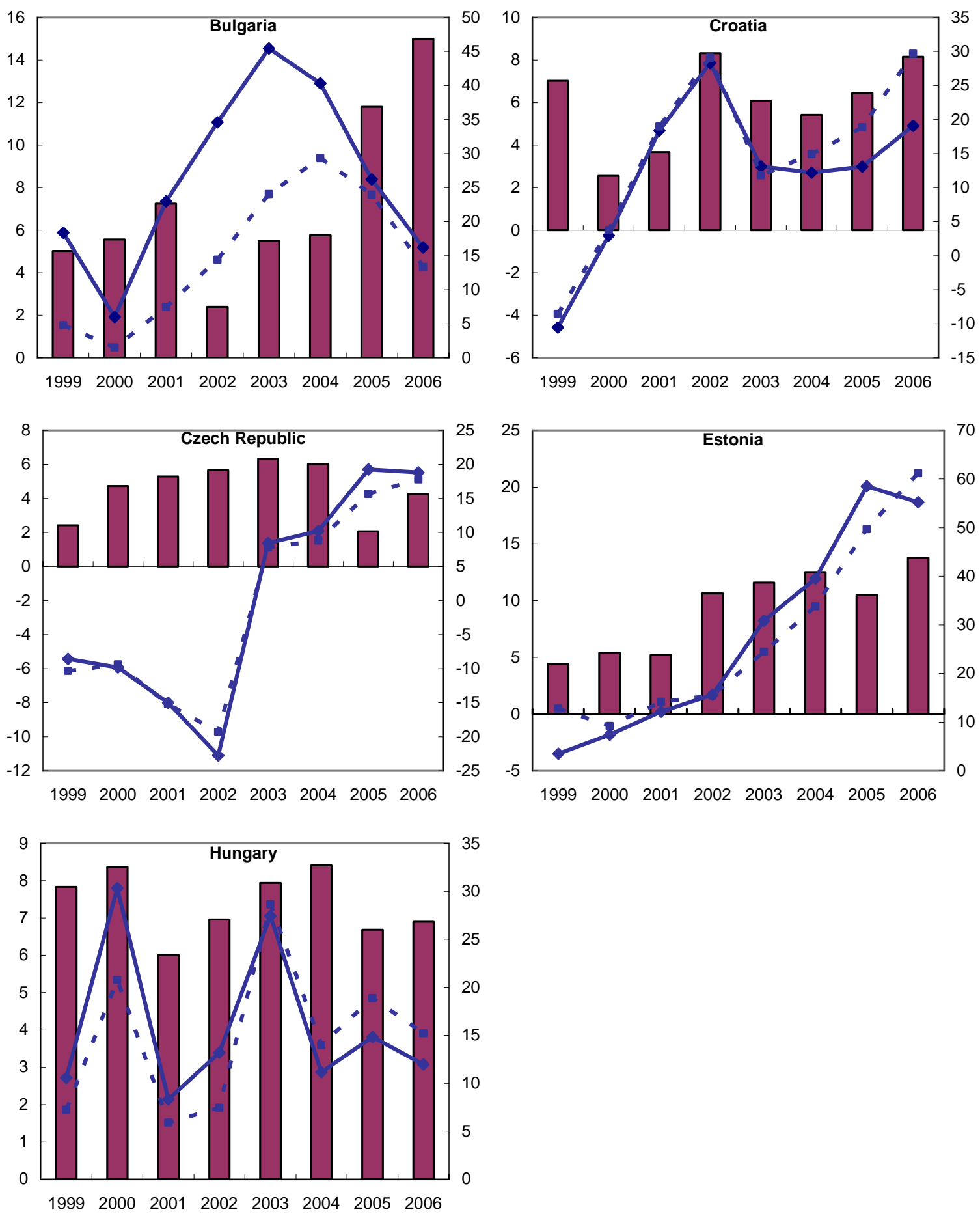

Current account deficit to GDP (LHS)

Real growth of bank credit (RHS)

- - Change in Bank credit to GDP (LHS)

Source: IFS, WEO, authors' calculations 
Figure 2 (Concluded). Selected European Countries: Current Account Balance and Credit Growth (in percent)
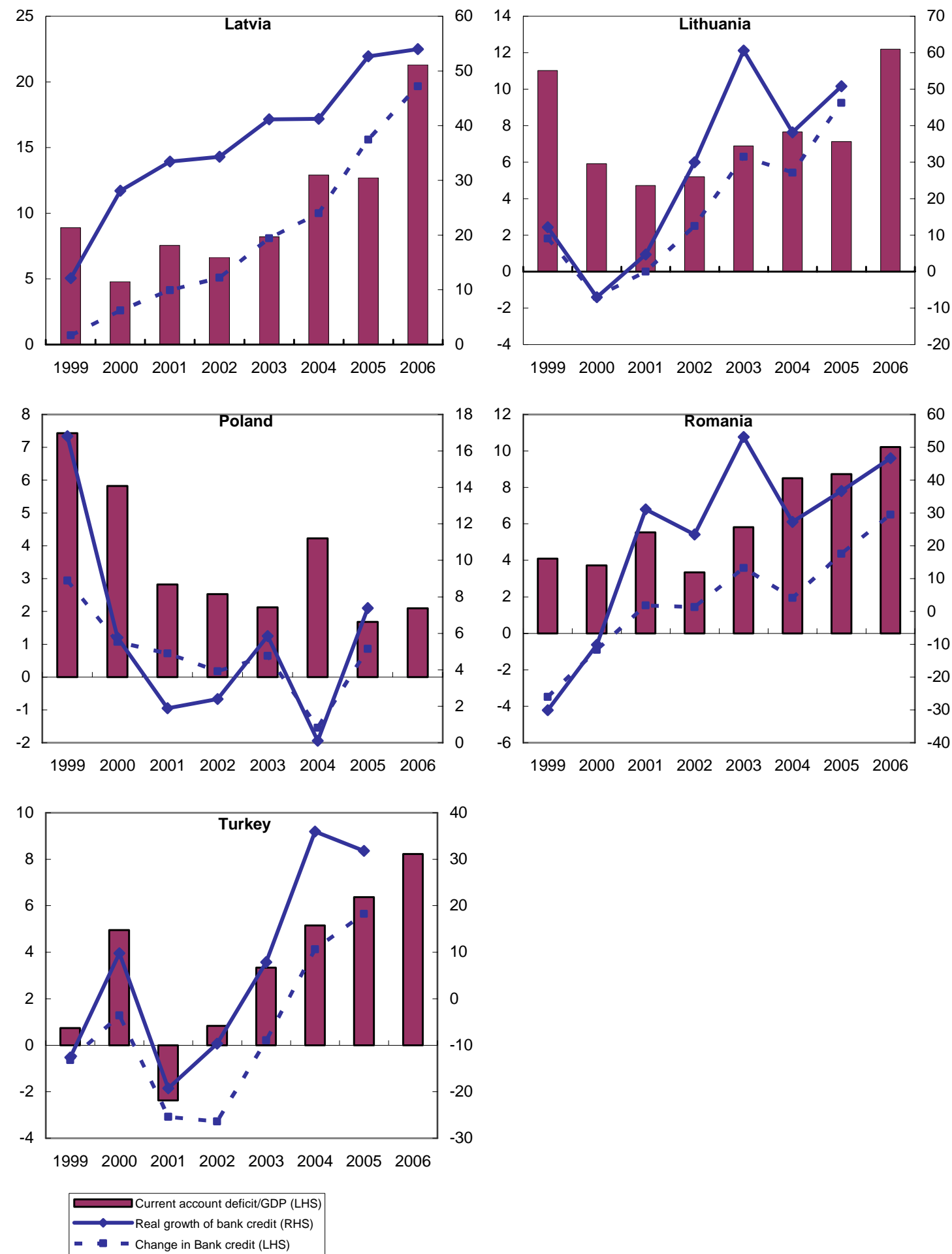

Source: IFS, WEO, authors' calculations 
Hungary, Latvia, Lithuania). ${ }^{12}$ Credit risk increased also through greater loan concentration in mortgage and household sectors (e.g., in the Baltics). The financial sector risks, combined with a deterioration in macro fundamentals made pegged exchange rates vulnerable to sudden inflow reversals (e.g., the Baltics and Hungary).

\section{Policy Responses to Capital Inflows}

Sample countries responded to the macroeconomic and financial sector implications of the inflows in a variety of ways, for which a number of factors have played a role. These included: (i) the monetary policy framework in place at the time, and (ii) the process of economic integration in the context of OECD membership and EU accession. Both of these factors have constrained the range of policy responses available to policymakers, leading in some cases to changes in the monetary policy or capital account regimes. The specific policy response has been shaped by whether the authorities' objective was to affect the flows themselves (e.g., their size and maturity composition, hence durability), or to deal with the complications they had brought (e.g., problems in achieving monetary or inflation targets, exchange rate regime vulnerability, worsening current accounts, and rising financial risks).

\section{A. Policy Responses During Periods of Exchange Rate Targeting}

When most countries maintained some form of exchange rate and/or monetary target, the policy response to the inflows aimed in general at addressing the impossible trinity dilemma. As the countries liberalized the capital account rapidly in integrating with global capital markets, attempts to simultaneously achieve (explicit or implicit) inflation and exchange rate targets put a strain on the existing mix of monetary and exchange rate policies (Croatia, the Czech Republic, Hungary, Israel, Poland, and Romania). Combined with predictable exchange rates, the high interest rates needed to reduce inflation attracted capital inflows, putting appreciation pressures on the currencies and pressuring the exchange rate targets. Faced with these trade-offs, the policymakers had to choose between affecting the inflows themselves or coping with their implications; in many cases a mix of both types of measures were adopted (Table 3 and Table 6 in Appendix I).

In dealing with the implications of the inflows, sterilized intervention was the most common response in many of the sample countries, though with mixed success. FX interventions needed to keep the exchange rate targets were sterilized to limit the impact on money supply and inflation. Such interventions proved unsustainable over long time periods, as they kept interest rates high, attracting further inflows, and led to large quasi fiscal costs that could potentially undermine the financial position of the central banks. In the Baltic countries and Bulgaria where the authorities had no independent monetary policy under the

\footnotetext{
${ }^{12}$ In Latvia, several foreign controlled banks have been seeking to expand and maintain market share, leading them to lower lending standards (IMF, 2006). In Lithuania, the riskiness of bank exposure to the household sector have been aggravated by several factors, including the softening of credit standards (Ramanauskas, 2007). High growth rates of some types of loans, strong competition and loosening of credit standards induced the authorities to increase close monitoring of the appropriateness of risk evaluation by banks (Bank of Lithuania, Financial Stability Review, 2005) and encourage banks for more prudent risk management and strengthen capital buffers during 2005-06 (IMF, 2007).
} 
hard peg regimes, reserve requirements have been the main tool for sterilization (through adjustments in the rate or the base of the requirement). The ability to sterilize the inflows was in general undermined by the lack of adequate monetary tools, high level of dollarization (euroization), relatively low level of financial sector development that hindered transmission of monetary policy, and the presence of foreign banks with easy access to foreign funds. ${ }^{13}$

\section{Except in Bulgaria and the Baltics, exchange rate changes were a common response to the macroeconomic implications of the inflows. Greater exchange rate flexibility helped resolve the tension between various policy targets by letting the appreciation absorb the impact of the inflows. ${ }^{14}$ Flexible rates also helped discourage short-term inflows by reducing the implicit exchange rate guarantees provided by the targets (see also Ötker-Robe and Vávra, 2007). Step appreciations were also undertaken (e.g., in Poland in December 1995), as well as successive reductions in the periodic depreciation rate of the exchange rate bands, to accommodate the appreciation pressures (Hungary, Israel, Poland). In the Baltics and Bulgaria, fiscal policy has been the main macro policy tool to mitigate the macroeconomic impact of the large inflows, given the lack of independent monetary policy. ${ }^{15}$}

\section{A number of countries adopted measures to affect the size and composition of the net FX inflows. Croatia and the Czech Republic imposed some controls on capital inflows in response to a surge in short-term inflows. ${ }^{16}$ External trade and FX systems were liberalized by several countries, including through elimination of import surcharges, tariffs, and surrender requirements (Bulgaria (1997), Hungary (1995-96), and Poland (1995-97)). By encouraging imports and permitting FX revenues to stay outside the country, such measures aimed at reducing the net inflow of foreign exchange into the country. In addition, capital}

\footnotetext{
${ }^{13}$ In Poland, the non-responsiveness of the partly reformed banking sector and segmented financial markets limited the transmission of policy rates to market rates in the late 1990s. Given the ineffectiveness of the traditional instruments, the NBP, in an unusual operation in late 1997, attracted deposits directly from the household sector to force banks to raise deposit and lending rates. Similarly in Croatia, sterilization efforts were undermined by the lack of effective monetary instruments. Since even very high interest rates on central bank bills failed to attract demand from the banks, the Croatian National Bank (HNB) temporarily used (until end1996) "obligatory HNB bills" that were remunerated at a rate higher than deposit rates but slightly lower than those on voluntary HNB bills. The high euroization of the economy continues to undermine the HNB's sterilization efforts at present.

${ }^{14}$ Greater flexibility was afforded, for example, by gradually widening exchange rate bands in the Czech Republic (1996), Hungary (2001), Israel (until 1997), and Poland (1995-99), and by a switch to floating exchange rates in the Czech Republic and Israel (in 1997), Poland (in 2000), and Romania (in 2004).

${ }^{15}$ Fiscal policy in general remained prudent in these countries, as the main tool for stabilization and to reduce external imbalances (Arvai, 2005, Lattemae, 2007, Lewis, 2005, and Kattai and Lewis, 2004), although there have been limits to the feasibility of maintaining fiscal surpluses for sustained periods of time (IMF Country Reports, various issues).

${ }^{16}$ Chilean-type inflow controls in Croatia (1998), including a deposit requirement for short-term foreign credits, and limits on banks' short-term open positions with nonresidents in the Czech Republic (1995). In the latter, the measure had only a limited effect in extending the maturity of the inflows as it was circumvented. In Croatia, they were effective in reducing the share of short-term inflows, but the controls on longer term financial credits and deposits were lifted in late 1998 after a market turmoil, making it difficult to assess their overall impact.
} 
outflows were liberalized with a view to reducing the net inflow of foreign exchange into the domestic economy (Bulgaria from 2000, the Czech Republic from 1995, Hungary and Israel in the late 1990s). ${ }^{17}$ The liberalizations in Poland and the Czech Republic were in part mandated by their commitments under EU accession and OECD membership.

\section{B. Policy Responses Under More Flexible Exchange Rates and Inflation Targeting}

The macroeconomic effects and policy implications of capital inflows have changed as most sample countries moved to managed or freely floating exchange rates and adopted IT regimes as the alternative monetary framework. Contrary to the inflationary pressures associated with monetary expansion under a pegged exchange rate regime, capital inflows under flexible rates involve some potential for leading to an undershooting of official inflation targets. The current account in general deteriorates with the inflows through real exchange rate appreciation under both regimes, though via different channels (higher inflation under pegged rates and no or partial sterilization, or nominal appreciation with flexible rates). ${ }^{18}$

\section{More flexible exchange rates accompanied by IT regimes have therefore added a new dimension to the challenges faced in responding to inflows. In principle, the following policy options were available in dealing with the macroeconomic implications of the inflows: allowing the exchange rate to absorb the impact of the inflows; intervening in the market to limit the extent of appreciation; reducing interest rates to discourage inflows; imposing administrative controls on the inflows, or tightening fiscal policy to reduce aggregate demand pressures. In practice, feasible policy options have been limited by the difficulty in determining the appropriate degree of monetary easing sufficient to discourage the inflows without undermining the inflation target, in gauging the appropriate role for intervention consistent with a float and an IT regime, and in maintaining fiscal surpluses on a permanent basis. Options have also been limited by the process of integration with the EU and international capital markets.}

Several countries let the exchange rate appreciate in response to the inflows under the flexible exchange rate regimes. In these countries (the Czech Republic after 1998, Hungary after 2001, Israel after 1997, Poland since 1998, Romania after late 2004, and Turkey after 2001), more flexible rates allowed the exchange rate to absorb the impact of the inflows, supporting the inflation targets while also helping discourage speculative inflows by imposing FX risks on those market participants that were incurring the risks. ${ }^{19}$ Concerns

\footnotetext{
${ }^{17}$ The literature on effectiveness of such measures on net inflows is inconclusive, however, given the potentially positive impact of such measures on market confidence in stimulating further inflows.

${ }^{18}$ For instance, in the earlier (1994-96) period of inflows to the Czech Republic, the pegged regime was weakened by monetary expansion, failure to prevent overheating, and large current account deficits. During the subsequent inflow episode in 2001-02 under IT, the currency appreciated markedly in nominal terms, and a prolonged stagnation was followed by worsening exports and an undershooting of inflation targets in 2003-04.

${ }^{19}$ Israel's experience is informative in this regard. The Bank of Israel (BoI) adopted a "crawling fan” regime and a non-intervention policy from mid-1997, in response to the pressures generated by attempting to simultaneously target inflation and the exchange rate. Under the fan, the band width was asymmetrically
}

(continued...) 
about undershooting the inflation target and adverse implications for external balances at times made the authorities reluctant to allow significant appreciation; ${ }^{20}$ (sterilized) FX interventions were used to limit the extent of nominal appreciation (the Czech Republic, ${ }^{21}$ Hungary, Israel, and Poland until June 1999).

In cases where the exchange rate was not allowed to adjust fully, clear and consistent communication of interventions in the broader context of the monetary policy regime proved essential in preserving the credibility of the IT regime. Only those interventions motivated by meeting the inflation targets are consistent with a full-fledged IT regime. Intervening for other purposes, such as concerns about competitiveness or exchange rate targets, has undermined the credibility of IT regimes in a number of these countries (Hungary, Israel until 1997, and Romania until 2005). ${ }^{22}$ The experiences also show that interventions may be ineffective in countering persistent FX pressures that reflect changes in macroeconomic fundamentals (e.g., in the Czech Republic, Israel, Poland, and Turkey).

The central banks have also actively used interest rate policies in responding to capital inflows under their IT regimes. Several central banks lowered their key policy rates to deal with the threat of undershooting medium-term inflation targets, to discourage, and hence reduce the proportion of, interest rate sensitive flows, and to limit the adverse consequences of exchange rate appreciation on the current account (the Czech Republic, Hungary, Poland, and Romania). Such monetary easing through interest rate cuts is consistent with the nature of the IT regime and is sustainable from a medium-term perspective as long as it is motivated by concerns about medium-term inflation targets. In Turkey, as well, interest rates were cut

widened on the more depreciated limit, while the more appreciated limit had been under attack; this approach raised the actual and potential variability of the exchange rate, and taking advantage of high domestic interest rates was no longer a virtual one-way bet. The BoI was able to stop intervention until the formal elimination of the band. The regime not only helped increase the perception of two-way exchange rate risks and led to a fall in the private sector's net foreign liabilities, but also helped the market learn to cope with exchange rate uncertainty, contributing to the development of FX hedging markets (Ötker-Robe and Vávra, 2007).

${ }^{20}$ For example, Romania was facing competitiveness concerns related to large capital inflows in 2004-05, which created some reluctance to allow rapid pace of exchange rate appreciation and raised policy tensions.

21 The appreciation of the koruna associated with capital inflows in the 2000s resulted in prolonged undershooting of inflation targets, despite efforts to limit the inflows and their implications for the targets. This was particularly true for the 2001-02 episode in which government induced FDI (e.g. privatization and government bond issuance) and other inflows replaced the “capacity building FDIs” (e.g., greenfield investment) of the late 1990s, and agreement was made on converting governmental FX proceeds in the central bank. While the nominal appreciation eventually came to an end (following a series of interest rate cuts, supported with interventions), the real appreciation had prolonged effects on economic activity and the external balance that kept inflation low until 2004 (see the CNB Inflation Reports, various issues).

22 In Israel, experience with sterilized intervention was unfavorable because it raised questions on commitment to the inflation target, while also leading to large quasi fiscal costs and undermining the BoI's capital. In Romania, the NBR intervened, at times significantly from mid to September 2005 on concerns about the sustained appreciation pressure and its implications for the current account. With insufficient support from fiscal and incomes policies the policy mix undermined the credibility of commitment to the inflation target. 
in 2003-05, but motivated mainly by the sharp downward trend in inflation following a successful macroeconomic stabilization.

Nevertheless, some countries experienced difficulties in reducing interest rates in the period of strong capital inflows. The difficulties were associated with the problems in working out the monetary policy transmission mechanism (especially in the earlier stages of the IT regimes when significant structural shifts occurred), and therefore in gauging the appropriate degree of monetary easing that would be consistent with the inflation targets (Hungary, Poland, Romania, and Turkey). There were also concerns about the adverse implications of low interest rates on credit growth, which could fuel inflation pressures (Romania and Turkey). Finally, interest rate reductions could be ineffective in reducing the overall level of the inflows if the bulk of the inflows were in the form of interest insensitive inflows (Israel).

Interest rate reductions hence needed to be undertaken cautiously under IT and be guided by reliable projections of inflation following an interest rate move. In this connection, it would be important to have a predictable and a well-functioning transmission mechanism; well-developed financial markets to transmit the effects of interest rate changes to inflation; a reasonable capacity to forecast inflation; a good understanding and careful monitoring of market conditions and trends for signs of possible future movements in the exchange rate; and adequate capacity to analyze the nature of the inflows (e.g., to assess how sensitive the inflows are to interest rate changes).

The sample countries with flexible exchange rates and inflation targets resorted, to a very limited extent, to fiscal tightening in responding to the inflows. Only Turkey tightened fiscal policy in response to concerns about overheating pressures. In Hungary and Poland, there were no signs of fiscal tightening as a reaction to large capital inflows during most of the period from the mid-1990s. The Czech Republic tightened fiscal policy only subsequently (Arvai, 2005). Loose fiscal policy in turn contributed to slower disinflation (Hungary) and large current account deficits (the Czech Republic), in some cases placing the burden of disinflation on monetary and exchange rate policies (Poland in the early 2000s and Hungary). In Romania as well, the fiscal and incomes policies were not sufficiently supportive of demand management efforts over the past few years, thereby putting the burden of disinflation on monetary and exchange rate policies.

\section{Challenges in Responding to Inflows Imposed by EU Integration}

The process of EU accession and membership with the OECD have also limited the available policy choices in responding to capital inflows. In particular, the scope for using administrative measures has been limited for those countries accessing the EU, since the adoption of the acquis has meant that the members had to abolish existing administrative systems for control and authorization of capital movements, and prepare a timetable for removing the restrictions on capital flows. Accordingly, there has been only a limited recourse to such measures in responding to capital inflows. Croatia and Romania took administrative measures in response to short-term inflows during 2004-06, but this was done more on account of concerns about macroeconomic stability and prudential risks associated 


\section{Table 3. Selected European Countries: Policy Responses to the Inflows, 1993-Present}

\begin{tabular}{|c|c|c|}
\hline Measures & Comment & Countries where adopted \\
\hline \multicolumn{3}{|c|}{ Measures to affect the size, composition, durability of the inflows } \\
\hline $\begin{array}{l}\text { Greater exchange rate } \\
\text { flexibility }\end{array}$ & $\begin{array}{l}\text { To help promote FX spot and derivatives market development; discourage } \\
\text { short-term speculative inflows. }\end{array}$ & Czech Republic, Israel, Poland \\
\hline $\begin{array}{l}\text { Reduction in interest } \\
\text { rates }\end{array}$ & $\begin{array}{l}\text { To discourage speculative inflows, to the extent interest sensitive flows are } \\
\text { important, there is a good system of monitoring flows, and a predictable, } \\
\text { functioning transmission mechanism exists. }\end{array}$ & Romania, Turkey \\
\hline Controls on inflows & $\begin{array}{l}\text { To help sustain the exchange rate by increasing maturity and reducing } \\
\text { volatility of the inflows; but conflict with requirements of the EU and OECD } \\
\text { integration processes. }\end{array}$ & $\begin{array}{l}\text { Czech Republic, Croatia, } \\
\text { Romania }\end{array}$ \\
\hline $\begin{array}{l}\text { Delays in liberalization } \\
\text { of certain inflows }\end{array}$ & $\begin{array}{l}\text { To help limit total inflow of capital; also caused conflicts with commitments } \\
\text { under OECD, EU. }\end{array}$ & Poland, Czech Republic, Israel \\
\hline $\begin{array}{l}\text { Liberalization of } \\
\text { outflows }\end{array}$ & $\begin{array}{l}\text { To help reduce net inflows and hence appreciation pressure on the currency, } \\
\text { though not clear whether potential positive impact on confidence may have } \\
\text { stimulated further capital inflows. }\end{array}$ & $\begin{array}{l}\text { Bulgaria, Czech Republic, } \\
\text { Hungary (late 1990s), Israel (late } \\
\text { 1990s) }\end{array}$ \\
\hline $\begin{array}{l}\text { Trade (tariffs, } \\
\text { surcharges) and FX } \\
\text { system (market access) } \\
\text { liberalization }\end{array}$ & $\begin{array}{l}\text { To reduce net FX inflows, especially in early integration stages, though not } \\
\text { clear whether potential positive impact on confidence may have stimulated } \\
\text { further capital inflows. }\end{array}$ & $\begin{array}{l}\text { Bulgaria (1997), Croatia (2001), } \\
\text { Poland (1995-97), Hungary } \\
(1995-97)\end{array}$ \\
\hline $\begin{array}{l}\text { Incentives for certain } \\
\text { types of inflows (FDI) }\end{array}$ & To help increase the maturity and reduce the volatility of inflows. & $\begin{array}{l}\text { Poland, Hungary, and after } 1997 \\
\text { Czech Republic, Lithuania }\end{array}$ \\
\hline \multicolumn{3}{|c|}{ Measures to cope with the implications of the inflows } \\
\hline $\begin{array}{l}\text { Greater exchange rate } \\
\text { flexibility }\end{array}$ & $\begin{array}{l}\text { To address the "impossible trinity" dilemma under increasingly open capital } \\
\text { accounts; while appreciation permitted could help reduce inflation, there was } \\
\text { also the risk of excessive appreciation undermining inflation targets and/or } \\
\text { competitiveness. }\end{array}$ & $\begin{array}{l}\text { Czech Republic, Hungary, Israel, } \\
\text { Poland, Romania }\end{array}$ \\
\hline $\begin{array}{l}\text { Reduction in interest } \\
\text { rates }\end{array}$ & $\begin{array}{l}\text { To a certain degree, to help limit risk of undershooting inflation targets; } \\
\text { problems in gauging the appropriate degree of reduction given difficulties in } \\
\text { estimating the monetary transmission mechanism, and fears of accelerating } \\
\text { credit and asset price growth. }\end{array}$ & $\begin{array}{l}\text { Czech Republic, Hungary, } \\
\text { Romania, Turkey }\end{array}$ \\
\hline Sterilized interventions & $\begin{array}{l}\text { To help deal with inflationary impacts of capital inflows; challenges } \\
\text { experienced with high interest rates inviting further inflows and with the } \\
\text { possibility of undermining credibility of flexible exchange rates and IT } \\
\text { regimes. }\end{array}$ & $\begin{array}{l}\text { Czech Republic, Hungary, Israel, } \\
\text { Poland, Turkey; Croatia and } \\
\text { Romania (limited) }\end{array}$ \\
\hline $\begin{array}{l}\text { Sterilization trough } \\
\text { reserve requirements } \\
\text { (higher ratio, delays in } \\
\text { reduction, broader base) }\end{array}$ & $\begin{array}{l}\text { Used as the only tool for sterilization in the absence of effective indirect } \\
\text { instruments or under fixed exchange rates, but at the risk of discouraging } \\
\text { financial intermediation and shifting activity offshore }\end{array}$ & $\begin{array}{l}\text { Bulgaria, Croatia, Estonia, } \\
\text { Latvia, Lithuania }\end{array}$ \\
\hline Tighter fiscal policy & To reduce overheating pressures caused by capital inflows. & Turkey \\
\hline $\begin{array}{l}\text { Strengthening prudential } \\
\text { regulation/supervision; } \\
\text { capital flows monitoring }\end{array}$ & $\begin{array}{l}\text { To help increase resilience of the financial system to volatile flows, reduce } \\
\text { risks of rapid credit growth, and help banks manage their direct/indirect FX } \\
\text { exposures and improve their internal risk management. }\end{array}$ & $\begin{array}{l}\text { Bulgaria, Estonia, Hungary, } \\
\text { Israel, Latvia, Lithuania, Poland, } \\
\text { Romania, Croatia (from 2000) }\end{array}$ \\
\hline $\begin{array}{l}\text { Debt management } \\
\text { measures }\end{array}$ & $\begin{array}{l}\text { To help reduce the liquidity implications of the inflows; and affect the } \\
\text { currency and maturity composition of the inflows }\end{array}$ & $\begin{array}{l}\text { Bulgaria, Croatia, Hungary, } \\
\text { Poland, Turkey }\end{array}$ \\
\hline $\begin{array}{l}\text { Indirect interventions } \\
\text { (special accounts at CB } \\
\text { for conversion of FX } \\
\text { revenues off the market) }\end{array}$ & $\begin{array}{l}\text { To reduce the amount of inflows (related mostly to privatization) that affected } \\
\text { the FX market, thereby to limit nominal appreciation and risks of } \\
\text { undershooting inflation targets. Tensions experienced, with such covert } \\
\text { interventions being potentially inconsistent with IT. }\end{array}$ & $\begin{array}{l}\text { Czech Republic, Poland, } \\
\text { Hungary }\end{array}$ \\
\hline
\end{tabular}

Source: Table 6 in Appendix I. 
with the rapid credit growth that had been increasingly funded by bank borrowing from abroad. In both countries, capital inflows and rapid credit growth have persisted (see Box 1).

While the other sample countries did not impose new capital controls, some used the possibility of delaying the liberalization of certain transactions depending on the intensity of capital inflows and developments in international markets. Under the EU accession commitments, the timetables for liberalization would typically allow for some transactions to be liberalized after the entry following an initial mass of liberalizations carried out before entry. Such strategies helped offset potentially destabilizing inflows to some degree, ${ }^{23}$ although the slowdown in the liberalization process caused by such sequencing led to tensions in the context of EU accession or OECD membership commitments (e.g., the Czech Republic in 1998).

A number of countries have retained the possibility of imposing new controls under their FX laws, but have not done so in practice (the Czech Republic, Hungary and Poland). The countries in general feared that such measures would be considered a significant step back in their economic development and liberalization process, jeopardizing the financial integration processes. However, the mere possibility of such measures may have had a disciplining effect on markets through moral suasion (see, e.g., Arvai, 2005). In Israel as well, the Chilean type of capital controls were considered on various occasions, but were ruled out to avoid policy reversals that could damage the hard-won credibility. The authorities also considered that such controls would be largely circumvented and hence would prove ineffective. Similarly in Turkey, the authorities have resisted the use of capital (or credit) controls given their EU aspirations, as well as the realization that any such control would be easily circumvented in the presence of a significant offshore market for the lira.

In a number of countries, capital account liberalization was carefully sequenced with the evolution of exchange rate regimes, development of financial markets, and improvements in prudential regulation:

- $\quad$ Capital account liberalization was better coordinated with greater exchange rate flexibility, with long-term inflows liberalized usually before short-term, and liberalization of the latter taking place in tandem with a gradual increase in flexibility (Israel and Poland - see Appendix II for a more detailed account of the liberalization experiences). Some countries also used FDI promotion policies to lengthen the maturity of the inflows, which also helped in linking the inflows to the investment needs of their economies (Hungary, Poland, and the Czech Republic after late 1990s). Liberalization of capital outflows helped reduce the pressure from the inflows (Bulgaria, Czech Republic, Hungary, Israel, Poland).

\footnotetext{
${ }^{23}$ During EU accession Hungary took a cautious approach to liberalization: controls were maintained on certain capital transactions, including on lending to nonresidents in domestic currency and derivative transactions, thereby helping limit speculation against the currency (Arvai, 2005). Romania postponed liberalization of certain capital transactions under its EU accession commitments, including restrictions on nonresident purchases of government securities and other controls on short-term capital until 2005. Poland and Israel deferred further liberalization of inflows and remaining capital account transactions at times of strong inflows.
} 


\section{Box 1. Responses to Credit Growth and Capital Inflows: Croatia and Romania}

Croatia and Romania are the only two countries in the sample that took administrative measures specifically responding to short-term inflows in recent years. The measures were imposed more on account of concerns about macroeconomic stability and prudential risks associated with the rapid credit growth that had been increasingly funded by bank borrowing from abroad.

- In Croatia, the measures took the form of an unremunerated marginal reserve requirement (MRR) on foreign borrowing in July 2004 (increased in steps during 2004-06 from 30 percent to 55 percent currently), with a view to reducing the external vulnerability and funding sources for FX-linked bank lending. These measures were accompanied by the introduction and broadening of FX liquidity requirements, moral suasion by the HNB to relax or tighten some of its instruments depending on banks' foreign borrowing, as well as by a number of supervisory and administrative measures to slow down the pace of rapid credit growth and improve management of the related risks. A unified supervisory agency for nonbank institutions was also established to better monitor the switch of private sector borrowing from banks to leasing companies in response to the regulations imposed on bank borrowing and lending.

- In Romania, a higher reserve requirement on all FX-denominated liabilities was introduced (mid-20042005) to curtail FX-denominated lending. The measure was combined with limits on banks' exposure to unhedged borrowers (300 percent of capital), and refinements in loan classification and provisioning requirements to take into account the FX risk of borrowers (see Table 6 in Appendix I for details).

In both countries, capital inflows and rapid credit growth have persisted:

- In Croatia, banks seem unwilling to raise their lending rates to offset the rising costs imposed by these measures, so as to preserve their market share. While the marginal reserve requirement (MRR) seems to have resulted in some scaling down of banks' borrowing plans after the rate was successively raised, an upturn has already been observed and banks have been seeking other ways to finance their activities. ${ }^{1}$ Moral suasion has had limited impact given the dominance of foreign banks. The CNB has responded to circumvention efforts by widening the scope of the existing regulations. The CNB also reintroduced direct controls on bank credit growth, effective in 2007. Imposing controls on direct borrowing by the private sector has been viewed unfavorably by the authorities given the EU membership aspirations.

- In Romania, strong credit growth with an FX component has remained throughout 2005-06 given persistent expectations of lei appreciation. Banks have adapted with a wave of loan exports by subsidiaries and by raising capital, rather than reducing FX-denominated loans, and by engaging in various window-dressing activities. After a brief decline, FX lending by banks resumed as banks increased their capital. The NBR removed the ceiling as of January 1, 2007, with cross border integration following EU membership making the measure increasingly less effective.

${ }^{1}$ These included, for example, using retained earnings, injection of capital by parent banks, or directing clients to them (i.e., direct borrowing by the private sector), and intensifying efforts to attract deposits.

- Improvements in prudential supervision and regulation have helped enhance the capacity to absorb the inflows (Bulgaria, the Czech Republic, Hungary, Israel, and Poland, as well as the Baltic's). Prudential and supervisory systems were strengthened with a view to increasing the resilience of the financial systems to risks. The process of bringing prudential regulations in line with international standards has been gradual, accelerated through harmonization with EU legislation during EU accession. From the early stages, the prudential frameworks in all countries have allowed banks to manage open currency positions and develop internal risk management systems.

- Countries also took steps to promote the development of their financial markets, thereby also helping to increase the capacity to absorb and manage the inflows. 
Financial sector reforms (e.g., reform of the nonbank financial supervision from 1998-99 and harmonization of the legislation with the EU in 2004-06 in Bulgaria, and improved access to FX markets in Croatia) improved the intermediation of capital inflows and broadened FX markets, facilitating better management of FX risks. In Israel, continuous development of domestic money and capital markets and an increased range and sophistication of monetary operations helped the BoI use marketbased instruments to implement monetary policy in dealing with the inflows.

Some countries also used a variety of debt management measures to cope with the implications of the inflows on the liquidity in the financial system (see also Arvai, 2005, and Kapteyn, Keller, and McGettigan, 2005). The authorities shifted from foreign to domestic borrowing sources (Bulgaria, Croatia, Hungary, Poland); bought back outstanding Brady discount bonds (Bulgaria and Poland); used the inflows to over-borrow and moved to medium and long-term domestic borrowing (Turkey); and used part of the privatization receipts to repay international financial organizations (Hungary). In some countries, government deposits were transferred to the central bank and the Deposit Insurance Fund was instructed to invest its cash balances and maturing repos in government debt to deal with the liquidity impact of inflows (Bulgaria).

Given the limited scope for administrative measures and the potentially adverse effect of FX interventions on the credibility of IT regimes, some countries also resorted to indirect intervention practices to limit the exchange rate impact of the inflows. Special accounts for government FX revenues (e.g., from privatization) were set up at the central bank with proceeds converted into domestic currency off the market via the central bank (the Czech Republic and Poland). These accounts were established after a public agreement between the central bank and government, having also a signaling effect. Moral suasion tools were also used (in Hungary, e.g., if a bank's on-balance sheet open position exceeded 30 percent of its capital the central bank reduced reserves remuneration and warned of stricter reserve requirements to stem inflows (Arvai, 2005)). Representing covert operations, such interventions raised at times question of consistency with IT and a floating exchange rate.

\section{Summary AND Policy Implications}

This paper described the experience with capital inflows of a number of countries in Europe. These countries experienced large-and sometimes disruptive-capital flows, stimulated by a number of predominantly country-specific factors, including large interest rate differentials, large scale privatization programs (including in the banking sector), and improved macroeconomic policy credibility and economic prospects, often associated with EU-related structural reforms.

The inflows were often helpful in promoting economic and financial development, but also complicated macroeconomic management and put a high premium on prudent policies. Policy tensions often arose since the authorities in many countries still sought to pursue multiple policy objectives even when opening the capital account. As a result, capital inflows led to rapid monetary expansion, a slowdown in the disinflation process, and wider current account deficits. These tensions have been relieved by the adoption of more flexible 
exchange rates and IT regimes, but continued capital inflows have still required a careful mix of interest rate and intervention policies to avoid disorderly exchange rate adjustments, while preserving the credibility of IT regimes. Inflows also posed risks to financial stability to the extent their intermediation resulted in a rapid growth of bank credit and maturity and currency mismatches in private sector balance sheets.

\section{Institutional improvements have helped strengthen the policy responses to capital inflows. Instead of capital controls, countries have been able to combine macroeconomic policy tools, to the extent available, with efforts to strengthen prudential regulation and supervision of financial systems, develop financial markets, better monitor capital flows, and adopt various debt management measures and some indirect intervention schemes.}

\section{The review of experience with the policy responses may provide useful lessons for} countries in similar situations experiencing large capital inflows. The experiences emphasize the importance of establishing positive initial conditions with good macroeconomic and financial fundamentals, and designing appropriate policy responses supported with a capital account liberalization process that is coherent, consistent and well-sequenced.

On the initial conditions, an efficient and well-regulated financial system, deeper financial markets, and capacity to design and implement sound policies are essential for an economy's ability to absorb the inflows and channel them into more productive uses. The availability of hedging instruments is particularly helpful in mitigating exchange rate volatility. Welldeveloped capital markets, by providing a richer array of investment options to financial institutions, can help reduce systemic vulnerability. Capacity to implement financial and monetary policies is key to managing capital inflows and transmitting the effects of policy changes (e.g., the skills and tools to analyze and manage the risks of currency and maturity mismatches, understanding the monetary transmission mechanism, and forecasting inflation).

The appropriate policy response will hence include a mix of mutually supportive policies and well-thought out steps to increase the absorption capacity and resilience of the systems to the potentially disruptive nature of the inflows. In particular:

- Greater exchange rate flexibility, where feasible, is often one of the best and most effective responses to large capital inflows, and part of a successful policy mix. Greater flexibility helps in mitigating the impact of the inflows and in reducing the perceptions of low exchange rate risk that could encourage unhedged FX positions. Timely efforts to put in place the necessary ingredients for a flexible exchange rate regime are hence crucial in defining an appropriate nominal anchor for monetary policy.

- $\quad$ Even with flexible exchange rates and a strong commitment to price stability, monetary policy may need to respond to exchange market pressures. Intervention to limit undue market volatility, but not to resist changes driven by macroeconomic fundamentals, is consistent with exchange rate flexibility. A good communication strategy and ensuring that risks are borne by those creating them are essential in using interest rate changes and interventions in a mutually compatible and reinforcing way. 
- Where monetary policy is constrained by a formal commitment to a pegged exchange rate, tightening fiscal policy and eliminating excessive fiscal incentives may be the only available option for aggregate demand management.

- Efforts should focus on reducing the risks and adverse consequences associated with the inflows, as opposed to affecting the flows and their composition:

- $\quad$ As countries become more integrated with international financial markets, there will be little room to use administrative measures in regulating capital flows effectively. Appropriate sequencing of liberalizing the remaining restrictions and debt management policies can, however, help in dealing with the implications of the inflows.

- $\quad$ Deepening the financial markets and strengthening the financial system supervision and regulation, where needed, would be the most effective ways to deal with the risks associated with capital inflows. Such approaches increase the absorption capacity and resilience of the economy to the inflows by helping to channel the inflows into their most productive uses. 


\section{APPENDiX I. FACTORS Motivating CAPITAL INFLOWS, THEIR IMPLICATIONS, AND POLICY RESPONSES}

\section{Table 4. Selected European Countries: Factors Underlying the Capital Inflows}

\begin{tabular}{|c|c|}
\hline Pull (Demand) Factors & Push (Supply) Factors \\
\hline \multicolumn{2}{|c|}{ Bulgaria (1997-present) } \\
\hline $\begin{array}{l}\text { - Liberalization of the foreign investment regime involving } \\
\text { reforms in legislative, accounting, information, and } \\
\text { institutional framework in the context of approaching the EU. } \\
\text { - Increased confidence in the economy with political and } \\
\text { economic stability (reduced external debt, low inflation). } \\
\text { - Sound economic and financial policy framework, supported } \\
\text { with CBA and structural reforms. } \\
\text { - High lending rates with limited perception of FX risks } \\
\text { - Rapid growth of banking sector credit financed increasingly } \\
\text { by bank borrowing from abroad (since early 2000s). }\end{array}$ & $\begin{array}{l}\text { - Dominance of the banking system by foreign banks } \\
\text { with easy access to foreign funds (including from } \\
\text { parent banks, especially in the recent years). } \\
\text { - Aggressive response of domestic banks to the entry } \\
\text { of foreign banks. }\end{array}$ \\
\hline \multicolumn{2}{|c|}{ Croatia (1993-present) } \\
\hline $\begin{array}{l}\text { - Improvement in market confidence in the economy and a } \\
\text { gradual integration of Croatia into the international financial } \\
\text { markets. } \\
\text { - Macroeconomic stabilization (price and exchange rate } \\
\text { - stability from 1994). } \\
\text { - Rehabilitation of the banking system (from 1995). } \\
\text { - Investment grade credit rating attained (in 1997). } \\
\text { - Stable exchange rates and higher domestic interest rates (and } \\
\text { - Rifferential with foreign interest rates). } \\
\text { by bank borrowing from abroad (since the early 2000s). }\end{array}$ & $\begin{array}{l}\text { - Paris and London Club debt agreements (in 1995- } \\
\text { 96). } \\
\text { - Arrival of foreign banks with easy access to foreign } \\
\text { funds (including from parent banks, especially in the } \\
\text { recent years). }\end{array}$ \\
\hline \multicolumn{2}{|c|}{ Czech Republic (1993-2004) } \\
\hline $\begin{array}{l}\text { - FDI promotion policies after } 1997 . \\
\text { - Privatization programs. } \\
\text { - Favorable macroeconomic performance and stability (until } \\
1997 \text { and after 2000) translating also into lower risk premia } \\
\text { - High interest rate differentials. } \\
\text { - Insufficient intermediation and supply of long-term } \\
\text { instruments by domestic banks that contributed to a rise in } \\
\text { direct financial credits from abroad. } \\
\text { - Foreign investors’ convergence play on the prospects of } \\
\text { E(M)U membership in 2001-02 and improved economic } \\
\text { prospects associated with EU membership. }\end{array}$ & $\begin{array}{l}\text { - Fall in world interest rates in 1993-95, attracting } \\
\text { foreign (mostly short term) inflows. }\end{array}$ \\
\hline \multicolumn{2}{|c|}{ Estonia (mainly since 2000) } \\
\hline $\begin{array}{l}\text { - Macroeconomic stability and associated increase in } \\
\text { confidence in the economy. } \\
\text { - EU convergence issues and associated reforms with the } \\
\text { prospect of imminent euro adoption. } \\
\text { - Privatization/deregulation of the financial sector that drew } \\
\text { foreign savings intermediated by reputable regional banks. } \\
\text { - Stable/predictable exchange rate and low perception of FX } \\
\text { risks under the currency board vis-à-vis the euro. } \\
\text { - Low nominal interest rates (given the currency board) leading } \\
\text { to negative real rates due to relatively high inflation, which in } \\
\text { turn contribute to the real estate boom and rapid credit growth. }\end{array}$ & $\begin{array}{l}\text { - Arrival of foreign banks who have been seeking } \\
\text { profitable opportunities and with easy access to } \\
\text { foreign funds (including from parent banks). }\end{array}$ \\
\hline
\end{tabular}




\begin{tabular}{|c|c|}
\hline Pull (Demand) Factors & Push (Supply) Factors \\
\hline \multicolumn{2}{|c|}{ Hungary (1995-present) } \\
\hline $\begin{array}{l}\text { - Improved confidence in macroeconomic stability, } \\
\text { performance, and prospects. } \\
\text { - Improved credibility of the narrow exchange rate band. } \\
\text { - High interest rate differentials owing to sterilization } \\
\text { operations that stimulated further inflows when combined } \\
\text { with predictable exchange rate movements within the narrow } \\
\text { exchange rate band. } \\
\text { - Relatively early liberalization of government securities } \\
\text { markets attracting interest rate sensitive inflows. } \\
\text { - Foreign investors' convergence play on the prospects of } \\
\text { E(M)U membership in 2001-02 and improved economic } \\
\text { prospects associated with EU membership. } \\
\text { - Rapid growth of banking sector credit since the early 2000s, } \\
\text { funded partly by bank borrowing from abroad. }\end{array}$ & $\begin{array}{l}\text { - Fall in world interest rates, attracting foreign (mostly } \\
\text { short term) inflows. } \\
\text { - Arrival of foreign banks with easy access to foreign } \\
\text { funds (including from parent banks, especially in the } \\
\text { recent years). }\end{array}$ \\
\hline \multicolumn{2}{|c|}{ Israel (1988-1998) } \\
\hline $\begin{array}{l}\text { - Credible low inflationary policies. } \\
\text { - High interest rate differentials with predictable exchange rate } \\
\text { movements and intra-marginal interventions within formal } \\
\text { bands. } \\
\text { - Improved macroeconomic performance and prospects. }\end{array}$ & $\begin{array}{l}\text { - Exogenous geopolitical events (also in connection } \\
\text { with the peace process), decreasing the country's risk } \\
\text { premium. }\end{array}$ \\
\hline \multicolumn{2}{|c|}{ Latvia (1998-present) } \\
\hline $\begin{array}{l}\text { - Strong economic growth and macroeconomic stability and } \\
\text { increased confidence in the economy (per capita income in } \\
\text { PPP terms climbed an impressive } 19 \text { percentage points in } \\
\text { 1997-2006, among the fastest of the eight new eastern } \\
\text { European member states (EU8) and until recently inflation } \\
\text { performance was commendable (1.9 percent in 2002, } \\
2.9 \text { percent in 2003, } 6.2 \text { percent in 2004, } 6.7 \text { percent in 2005, } \\
\text { and } 6.5 \text { percent in 2006). } \\
\text { - EU accession and prospects of euro adoption. } \\
\text { - Elimination of all capital controls. } \\
\text { - Stable/predictable exchange rates and perception of low FX } \\
\text { risks under the long-standing fixed peg regime since } 1994 \text {. } \\
\text { - Low nominal interest rates leading to negative real rates due } \\
\text { to relatively high inflation, which in turn contributed to the } \\
\text { real estate boom. }\end{array}$ & $\begin{array}{l}\text { - Arrival of foreign banks with easy access to foreign } \\
\text { funds (including from parent banks). } \\
\text { - The need to cofinance projects supported from EU } \\
\text { structural funds. }\end{array}$ \\
\hline \multicolumn{2}{|c|}{ Lithuania (mid-late 1990s and 2002-present) } \\
\hline $\begin{array}{l}\text { - Impressive growth in per capita income toward the European } \\
\text { average underpinned by robust productivity growth, increased } \\
\text { confidence in the economy, and improved prospects } \\
\text { associated with EU accession, which has gained momentum } \\
\text { from } 2003 \text {. } \\
\text { - Privatization/deregulation of banks that attracted foreign } \\
\text { capital under a liberalized capital account. } \\
\text { - Stable/predictable exchange rates and perception of low FX } \\
\text { risks under the currency board arrangement. }\end{array}$ & $\begin{array}{l}\text { - Arrival of foreign banks with easy access to foreign } \\
\text { funds ( } 5 \text { of } 9 \text { banks in Lithuania are subsidiaries of } \\
\text { foreign banks and } 4 \text { are branches of foreign banks). } \\
\text { - The need to cofinance projects supported from EU } \\
\text { structural funds. }\end{array}$ \\
\hline \multicolumn{2}{|c|}{ Poland (1991-2005) } \\
\hline $\begin{array}{l}\text { - Improvement in economic conditions, with greater macro- } \\
\text { economic stability and EU accession prospects (from 1994). } \\
\text { - Privatization and growth of the Polish capital market (from }\end{array}$ & $\begin{array}{l}\text { - London Club agreement (1994). } \\
\text { - Global ample liquidity following interest rate cuts in } \\
\text { the United States (2001-05). }\end{array}$ \\
\hline
\end{tabular}




\begin{tabular}{|c|c|}
\hline Pull (Demand) Factors & Push (Supply) Factors \\
\hline $\begin{array}{l}\text { 1991). } \\
\text { - Large interest rate differentials (in the 1990s, adjusted for } \\
\text { expected exchange rate depreciation), combined with } \\
\text { predictable exchange rate movements and intra-marginal } \\
\text { interventions within the formal bands (1992-99). } \\
\text { - Increasing confidence in monetary management (from 1992). } \\
\text { - Declining corporate income tax rates (over time lower than in } \\
\text { most EU countries) (from 1997). }\end{array}$ & \\
\hline \multicolumn{2}{|c|}{ Romania (2004-present) } \\
\hline $\begin{array}{l}\text { First stage of privatization program. } \\
\text { - Improved economic prospects in the context of EU accession. } \\
\text { - Increase in capitalization of foreign companies already } \\
\text { operating in Romania. } \\
\text { - A surge in bank borrowing from abroad since mid-2001 in } \\
\text { part to fund the rapid growth of banking system credit. } \\
\text { - Speculative inflows driven by high interest rate differentials } \\
\text { and predictable exchange rate movements until } 2005 .\end{array}$ & $\begin{array}{l}\text { Increasing role and share in the banking system of } \\
\text { foreign banks with easy access to foreign funds } \\
\text { (including from their parent banks especially in the } \\
\text { recent years). }\end{array}$ \\
\hline \multicolumn{2}{|c|}{ Turkey (2003-2004) } \\
\hline $\begin{array}{l}\text { - Prospects of EU entry (in 2000s). } \\
\text { - High interest rate differentials. } \\
\text { growthe supported by structural reforms. } \\
\text { - Increased credibility of monetary policy with significant } \\
\text { disinflation and consolidation of public finances. }\end{array}$ & $\begin{array}{l}\text { - Abundant international liquidity and low interest } \\
\text { rates in advanced economies in 2000s. } \\
\text { - Hedging needs of foreign issuers (multilateral } \\
\text { institutions, international banks, and export credit } \\
\text { agencies) of new TL papers, following the lira’s } \\
\text { redenomination. }\end{array}$ \\
\hline
\end{tabular}

Sources: Enoch and Ötker-Robe (2007), Hilbers, Ötker-Robe, Pazarbasioglu, and Johnsen (2005), Kapteyn, Keller, and McGettigan (2005) in EBS/05/67, Ötker-Robe and Vávra (2007), Arvai (2005), IMF Country Reports (various countries and issues) and the national central banks of the countries included in this paper. 
Table 5. Selected European Countries: Macroeconomic and Financial Implications of Inflows

\begin{tabular}{|c|c|}
\hline Macro Impact & Financial Sector Impact \\
\hline \multicolumn{2}{|c|}{ Bulgaria (1997-present) } \\
\hline $\begin{array}{l}\text { - Helped improve productivity and export performance. } \\
\text { - Helped financing of CA deficits. } \\
\text { - In the later periods, when other investment inflows caused } \\
\text { difficulties in monetary management especially under the } \\
\text { CBA with limited room for monetary policy maneuver and } \\
\text { lack of traditional monetary instruments to manage liquidity } \\
\text { (the reserve requirement as the only monetary instrument). }\end{array}$ & $\begin{array}{l}\text { - Helped post- post-crisis restructuring of the financial } \\
\text { sector, through privatization. } \\
\text { - Contributed to development of financial markets, } \\
\text { through rising volumes of transactions. } \\
\text { - Since early 2001, facilitated the rapid increase in } \\
\text { credit growth with a significant FX component, } \\
\text { which has been raising financial stability concerns } \\
\text { associated with indirect FX exposure of banks and } \\
\text { deterioration in banks' risk assessment and internal } \\
\text { control systems; some disintermediation that took } \\
\text { place toward lending by nonbank financial } \\
\text { institutions not subject to reserve requirements or } \\
\text { similar supervisory scrutiny also raises stability } \\
\text { concerns for the overall financial sector. }\end{array}$ \\
\hline \multicolumn{2}{|c|}{ Croatia (1993-present) } \\
\hline $\begin{array}{l}\text { - Associated with a widening of the CA deficit. } \\
\text { - Associated with a rapid monetary expansion, when } \\
\text { sterilization was complicated by a high degree of } \\
\text { euroization and lack of appropriate monetary instruments } \\
\text { (inflationary impact has been limited by reverse currency } \\
\text { substitution at the earlier stages and exchange rate stability } \\
\text { and wage moderation in the later stages). } \\
\text { - Rapid increase in the external indebtedness of banks and the } \\
\text { corporate sector as they borrow from abroad (banks in } \\
\text { financing their rapid lending growth, corporates in part in } \\
\text { response to the direct/indirect measures imposed on bank } \\
\text { lending). }\end{array}$ & $\begin{array}{l}\text { - Volatile short term inflows contributed to FX market } \\
\text { instability in 1998/99 period. } \\
\text { - The currency mismatch (direct FX risk) in the } \\
\text { balance sheets of commercial banks (as banks } \\
\text { borrowed in foreign currency and lent in kuna) } \\
\text { contributed to two banking crises (mid and late } \\
\text { 1990s). } \\
\text { - Significant rise in recent years in foreign currency } \\
\text { related lending to unhedged borrowers financed } \\
\text { largely by banks' foreign borrowing exposes the } \\
\text { financial system to indirect FX risks and risks of a } \\
\text { potential deterioration in asset quality if the } \\
\text { exchange rate were to depreciate. } \\
\text { - The measures imposed to limit credit growth or its } \\
\text { financing in the form of bank borrowing from abroad } \\
\text { led to some circumvention efforts in the form of } \\
\text { switch to borrowing from less well-regulated } \\
\text { nonbank financial institutions (e.g., leasing } \\
\text { companies), with the associated stability risks for the } \\
\text { overall financial sector. }\end{array}$ \\
\hline \multicolumn{2}{|c|}{ Czech Republic (1993-2004) } \\
\hline $\begin{array}{l}\text { - Improved technological possibilities, export performance, } \\
\text { and competitiveness. } \\
\text { - Helped financing of CA deficits. } \\
\text { - Led to rapid monetary expansion and large sterilization } \\
\text { needs under the pegged exchange rate--holy trinity } \\
\text { dilemma. } \\
\text { - Insufficient coordination of fiscal policy with monetary } \\
\text { policy under a fixed exchange rate required higher interest } \\
\text { rates that helped attract further inflows. } \\
\text { - Complications in achieving the inflation targets under the } \\
\text { free float (causing a significant undershooting of the targets }\end{array}$ & $\begin{array}{l}\text { - Entrance of foreign banks in the form of either } \\
\text { branches or subsidiaries had a role in developing the } \\
\text { interbank, FX and bank-client markets, and was also } \\
\text { an important stabilizing element in terms of } \\
\text { managing FX risks. } \\
\text { - Participation of foreign banks in the privatization of } \\
\text { major state banks lead to a mixed experience as } \\
\text { regards financial sector stability, although it overall } \\
\text { increased the efficiency of both the banking sector, } \\
\text { as well as (indirectly) corporate management. }\end{array}$ \\
\hline
\end{tabular}




\begin{tabular}{|c|c|}
\hline Macro Impact & Financial Sector Impact \\
\hline in) during 1999-2004. & \\
\hline \multicolumn{2}{|c|}{ Estonia (mainly since 2000 ) } \\
\hline $\begin{array}{l}\text { - Inflows intermediated through the banking system have } \\
\text { been supporting a strong growth of banking sector credit } \\
\text { (especially since 2002); the latter has contributed to } \\
\text { overheating pressures in the economy: } \\
\text { - a sharp deterioration of the current account deficit (to an } \\
\text { estimated } 15 \text { percent of GDP in 2006, compared with } \\
5 \text { percent in 2001). } \\
\text { - the } 2008 \text { target for euro adoption pushed back (until } \\
\text { 2011) owing to the difficulties in meeting the inflation } \\
\text { criteria. } \\
\text { - Growing external indebtedness (with net external liabilities } \\
\text { (NFL) approaching } 100 \text { percent of GDP by end-2006) } \\
\text { increased vulnerability to a sudden reversal of market } \\
\text { sentiment for Estonia or the region. A mitigating factor is } \\
\text { that equity investment was the main driver of the build-up } \\
\text { of external liabilities. } \\
\text { - Contribution to productivity and enhanced competitiveness. }\end{array}$ & 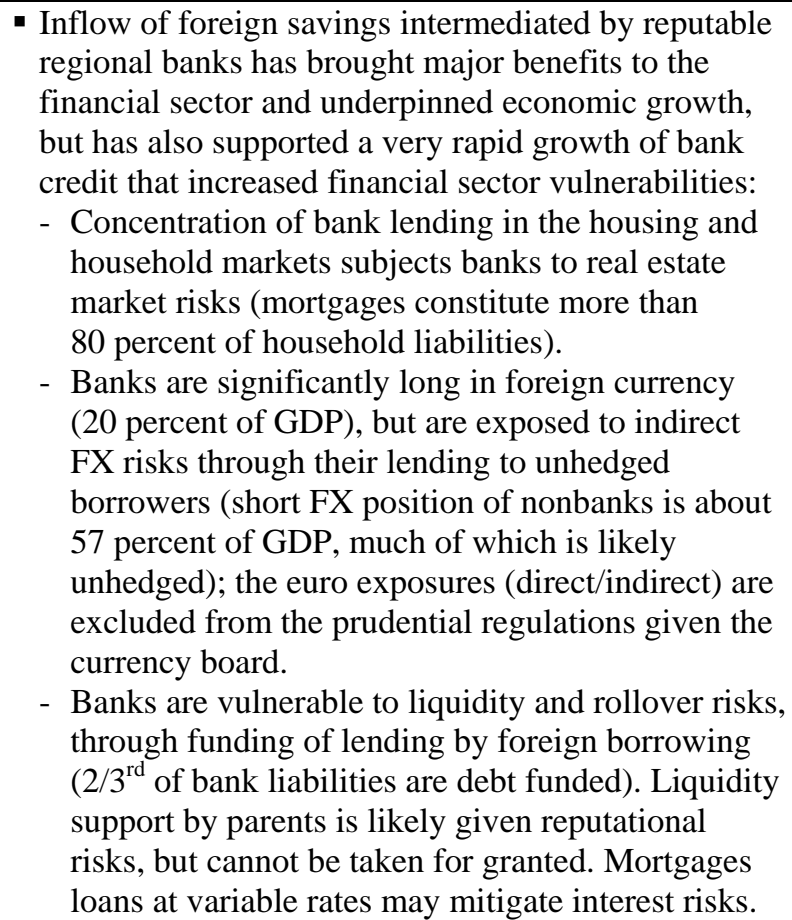 \\
\hline \multicolumn{2}{|c|}{ Hungary (1995-present) } \\
\hline $\begin{array}{l}\text { - Helped finance CA and public sector deficits. } \\
\text { - In the early period, no significant macroeconomic effects } \\
\text { observed in mid-1990s, in part due to sterilization efforts. } \\
\text { - Persistent inflows complicated policy implementation as the } \\
\text { authorities aimed at maintaining the exchange rate band } \\
\text { while simultaneously targeting inflation: higher interest } \\
\text { rates to counter inflation (in the absence of sufficiently tight } \\
\text { fiscal policies and exchange rate flexibility) continued to } \\
\text { attract inflows, as well as stimulating FX-linked lending. } \\
\text { - Inflows intermediated through the banking system to } \\
\text { support a rapid expansion of credit have been associated } \\
\text { with a widening current account deficit (via higher imports } \\
\text { and consumption), which, when combined with fiscal } \\
\text { deficits raised concerns about currency stability. }\end{array}$ & $\begin{array}{l}\text { - Rapid expansion of credit made possible in part by } \\
\text { foreign borrowing by banks contributed to financial } \\
\text { stability concerns (after 2000): in particular rising } \\
\text { foreign currency lending exposed the banking sector } \\
\text { to indirect FX risks (to the extent borrowers were not } \\
\text { hedged). There is some deterioration in banks' } \\
\text { lending standards given the intense competition for } \\
\text { market shares. }\end{array}$ \\
\hline \multicolumn{2}{|c|}{ Israel (1988-1998) } \\
\hline $\begin{array}{l}\text { Trade off between the objectives of achieving low inflation } \\
\text { and preserving competitiveness under heavy capital inflows } \\
\text { complicated monetary policy management; sterilizations to } \\
\text { offset monetary expansion became costly, leading } \\
\text { eventually to greater exchange rate flexibility. }\end{array}$ & $\begin{array}{l}\text { No significant financial sector implications were } \\
\text { observed. }\end{array}$ \\
\hline \multicolumn{2}{|c|}{ Latvia (1998-present) } \\
\hline $\begin{array}{l}\text { - Widening CA deficit (to } 21 \text { percent of GDP in 2006) more } \\
\text { than financed by banks' net foreign borrowing and deposit } \\
\text { taking ( } 22.4 \text { percent of GDP) }\end{array}$ & $\begin{array}{l}\text { - The persistently strong growth in bank lending } \\
\text { financed largely by bank borrowing from abroad } \\
\text { contributed to financial vulnerabilities: }\end{array}$ \\
\hline
\end{tabular}




\begin{tabular}{l} 
Macro Impact \\
\hline - FX market pressures and exchange rate risks associated \\
with sizable external imbalances: NFL rose to 69 percent of \\
GDP in 2006; unlike other EU8-where net equity (FDI \\
and portfolio) accounts for the largest share of NFLs-in \\
Latvia, more than half of NFL is in the form of net debt, \\
which rose from 9 percent of GDP in 1999 to 43 percent in \\
2006 . \\
- Rising inflation pressures led to a delay in the target date of \\
euro adoption in 2008- to at least 2012). \\
- Inflows have been supporting a very strong growth of bank \\
lending. Concentration of loans to households and non- \\
tradable sectors presents an obstacle to long-term \\
production capacity (in 2003-06, over 61 percent of new \\
loans were used to finance residential mortgages or \\
corporate real estate; 11 percent for other loans to \\
households; and 6 percent to manufacturing). While credit \\
growth has raised well-being of households, there have \\
been limited benefits for sectors that could generate export \\
earnings. \\
- With the small share of FDI directed to the manufacturing \\
sector (14 percent in 2005-the smallest among EU8), \\
Latvia is missing out on the productivity-enhancing benefits \\
of FDI in export-oriented manufacturing sectors.
\end{tabular}

\begin{tabular}{l} 
Lithuania (mid-late 1990 \\
\hline - Contribution to overheating pressures in the economy with a \\
rising current account deficit and inflation pressures: \\
- Concerns about sustainability of the current account \\
deficit with continued strength of the credit expansion \\
financed substantially by external borrowing; the credit \\
expansion supported domestic demand and imports; non- \\
FDI financing component of the current account deficit \\
has been increasing. \\
- The recent pick up in inflation will likely remain above \\
the Maastricht criteria as long as demand pressures \\
continue; target date for euro adoption moved until at \\
least 2010. \\
- Increasing external debt through banking sector borrowing \\
from abroad raises vulnerability to a sudden reversal of \\
market sentiment toward Lithuania or the region.
\end{tabular}

Poland (1991-2005)

- Helped improve the technological possibilities and create a competitive export sector.

- Contributed to economic overheating, with stability risks.

- Complicated monetary policy management through costly sterilizations, which led to step-wise increases in exchange rate flexibility to safeguard the disinflation process; the

Financial Sector Impact

- Reliance on foreign borrowing by banks has increased vulnerability to liquidity and rollover risks; banks account for half of Latvia's foreign debt assets and $2 / 3^{\text {rd }}$ of its foreign debt liabilities.

- Banks have increasing exposure to FX-related credit and market risks via balance-sheet mismatches of their unhedged foreign currency borrowers.

- Intensifying competition among banks for market share contributed to a softening of loan standards (e.g., an easing of mortgage origination standards). 


\begin{tabular}{|c|c|}
\hline Macro Impact & Financial Sector Impact \\
\hline $\begin{array}{l}\text { authorities eventually switched to an inflation targeting } \\
\text { regime in } 1998 \text { with a floating exchange rate adopted in } \\
2000 .\end{array}$ & $\begin{array}{l}\text { nonperforming) loans. These loans presented a risk } \\
\text { to financial stability in the early 1990s; the stronger } \\
\text { supervisory system in the 1990s helped deal with the } \\
\text { negative effects of the rapid credit growth. }\end{array}$ \\
\hline \multicolumn{2}{|c|}{ Romania (2004-present) } \\
\hline $\begin{array}{l}\text { Deterioration of macroeconomic balances: expansion in } \\
\text { domestic demand, a widening CA deficit, competitiveness } \\
\text { concerns, and a slow down in the process of disinflation. } \\
\text { - Exacerbated the trade off between simultaneous attainment } \\
\text { of competitiveness and inflation goals, limiting monetary } \\
\text { policy autonomy and jeopardizing the inflation target: } \\
\text { raising interest rates attracted further inflows and higher FX } \\
\text { denominated lending while lowering interest rates risked } \\
\text { credibility of the inflation target adopted in mid-2005. }\end{array}$ & $\begin{array}{l}\text { - Capital inflows facilitated a rapid growth of credit to } \\
\text { the private sector with a significant FX component, } \\
\text { exposing the banking system to indirect FX risks; } \\
\text { some pressure on profitability has also been } \\
\text { observed. }\end{array}$ \\
\hline \multicolumn{2}{|c|}{ Turkey (2003-2005) } \\
\hline $\begin{array}{l}\text { - Appreciation pressures under a floating exchange rate have } \\
\text { raised competitiveness concerns (and were associated with } \\
\text { a significant widening of the CA deficit); exchange rate } \\
\text { intervention under the floating exchange rate since } 2001 \\
\text { aimed mainly to build a sufficient stock of reserves. } \\
\text { - Inflows increased the premium placed on an appropriate } \\
\text { policy mix; continuation of disinflation may require interest } \\
\text { rates to remain high for a while, which is likely to sustain } \\
\text { capital inflows. }\end{array}$ & $\begin{array}{l}\text { - Recent inflows contributed to a rising share of fixed } \\
\text { term consumer lending, exposing the banking system } \\
\text { to interest rate risks. On the other hand, greater } \\
\text { reliance on (more long-term) foreign financing has } \\
\text { served to mitigate somewhat maturity mismatches in } \\
\text { Turkish banks, although faster credit expansion has } \\
\text { created other vulnerabilities, including greater } \\
\text { exposure to credit risk. }\end{array}$ \\
\hline
\end{tabular}

Sources: Adahl (2002), Arvai (2005), Enoch and Ötker-Robe (2007), Hilbers, Ötker-Robe, Pazarbasioglu, and Johnsen (2005), Kapteyn, Keller, and McGettigan (2005) in EBS/05/67, Lewis (2005),Kattai and Lewis (2004), Ötker-Robe and Vávra (2007), Schipke, Beddies, George, and Sheridan (2004), IMF Country Reports (various countries and issues), and the national central banks of the countries included in this paper. 
Table 6. Selected European Countries: Policy Responses to the Capital Inflows

\begin{tabular}{|c|c|}
\hline Policy Responses & Impact \\
\hline \multicolumn{2}{|c|}{ Bulgaria (1997-2006) } \\
\hline $\begin{array}{l}\text { - Financial sector reforms (legal and institutional framework } \\
\text { for foreign investment made EU compatible, and strengthening } \\
\text { the prudential and supervisory framework. } \\
\text { - Appropriate information systems for financial flows } \\
\text { integrating all foreign investments, statistical tools to gather } \\
\text { information on cross-border financial flows, and reporting } \\
\text { requirements on financial institutions, legal entities, and } \\
\text { physical persons. } \\
\text { - Liberalization of FX and capital account regime from } 2000 \\
\text { and acceleration of trade liberalization from 1997. } \\
\text { - Credible and consistent macroeconomic policy mix } \\
\text { (including transparent monetary policy based on CBA). } \\
\text { - Supervisory, monetary, and administrative measures to } \\
\text { slow down the pace of rapid credit growth financed largely by } \\
\text { inflows intermediated by the banking system (e.g., raising the } \\
\text { level and broadening the coverage of reserve requirements to } \\
\text { liabilities previously exempted; further tightening of prudential } \\
\text { and supervisory regulations; moral suasion to convince banks } \\
\text { to reduce credit growth; credit controls in the form of a } \\
\text { nonremunerated reserve requirement on excessive credit } \\
\text { growth) (2004-06). }\end{array}$ & $\begin{array}{l}\text { - These measures helped in managing the capital flows, including } \\
\text { by increasing the financial system's absorption capacity of the } \\
\text { inflows. In particular, it provided greater freedom to banks in } \\
\text { managing their open foreign currency positions, including those } \\
\text { associated with capital flows, while obligating them to develop } \\
\text { internal risk management systems in line with best international } \\
\text { practices. } \\
\text { - May have helped somewhat reduce net FX inflows into the } \\
\text { domestic economy. } \\
\text { - Helped limit potential adverse consequences of increased } \\
\text { inflows. } \\
\text { - These measures were taken not to limit capital inflows per se, } \\
\text { but to deal with their implications through expansion of credit } \\
\text { funded by such inflows. Overall, moral suasion was ineffective } \\
\text { (given the dominance of foreign banks operating under home } \\
\text { country regulations); tighter reserve requirements mainly served } \\
\text { as a warning; while the supervisory, administrative measures } \\
\text { helped slow credit growth, they also resulted in some dis- } \\
\text { intermediation and circumvention efforts that transferred some } \\
\text { of the activity to potentially riskier funding of borrowers; the } \\
\text { latter required in turn a widening of the scope of the measures } \\
\text { and efforts to strengthen nonbank financial sector supervision. } \\
\text { - Helped deal with the liquidity impact of the inflows. }\end{array}$ \\
\hline \multicolumn{2}{|c|}{ Croatia (1993-2006) } \\
\hline $\begin{array}{l}\text { - Limited scale sterilization initially through reserve } \\
\text { requirements and 'obligatory’ CB bills (remunerated at above } \\
\text { deposit rates but below standard CB bill rates), later through } \\
\text { foreign currency denominated CB bills (at market rates). } \\
\text { - FX market liberalization in 2001, including by allowing } \\
\text { banks full access to the FX market (including to hold foreign } \\
\text { currency in their accounts, and not only when justified by } \\
\text { import needs as previously) and extension of surrender } \\
\text { requirement period for conversion of FX receipts of the } \\
\text { corporate sector. }\end{array}$ & $\begin{array}{l}\text { - Sterilization efforts have been thwarted by a high degree of } \\
\text { euroization preventing effective development of monetary } \\
\text { policy instruments; obligatory CB bills were introduced, } \\
\text { because standard bills did not attract enough liquidity. } \\
\text { - The measures have helped i) better manage corporate FX risks } \\
\text { (by enabling companies to freely decide on the currency } \\
\text { composition of their portfolio holdings); ii) deepen and broaden } \\
\text { the relatively shallow foreign exchange market (in turn } \\
\text { facilitating better management by all market participants of the } \\
\text { risks associated with capital flows), iii) improve financial } \\
\text { intermediation of the capital inflows (together with the efforts to } \\
\text { strengthen the banking system following the banking crisis of } \\
\text { 1998-2000, including through opening the sector to foreign } \\
\text { capital and strengthening its supervision and regulation). } \\
\text { - Initially, the controls were instrumental in decreasing the share } \\
\text { of short-term inflows; controls on longer term financial credits } \\
\text { and deposits were abolished soon (in late } 1998 \text { following } \\
\text { international market turbulences). }\end{array}$ \\
\hline
\end{tabular}




\begin{tabular}{|c|c|}
\hline Policy Responses & Impact \\
\hline $\begin{array}{l}\text { - Debt management measures: The authorities shifted from } \\
\text { foreign to domestic borrowing sources. }\end{array}$ & $\begin{array}{l}\text { - Helped cope with the implications of the inflows on the } \\
\text { liquidity of the financial system. }\end{array}$ \\
\hline $\begin{array}{l}\text { Fiscal adjustment and a mix of prudential, supervisory, } \\
\text { and administrative measures to reduce capital inflows, with } \\
\text { a view to limiting the accumulation of external debt and } \\
\text { expansion of credit, where the exchange rate stability objective } \\
\text { and high euroization of the economy limited the capacity to } \\
\text { use traditional monetary instruments: } \\
\text { (Unremunerated) marginal reserve requirement (MRR) } \\
\text { on banks' new foreign borrowing (7/2004) to slowdown } \\
\text { bank-related portion of capital inflows that has funded } \\
\text { much of the bank credit expansion; the rate was increased } \\
\text { several times (to } 55 \text { percent currently) and the base was } \\
\text { broadened in } 2005 \text { (e.g., to include banks' guarantees to } \\
\text { companies/individuals who directly borrow from abroad, } \\
\text { and deposits received by banks from leasing companies not } \\
\text { related to them, and to introduce a special reserve } \\
\text { requirement of } 55 \text { percent for issued securities for FX- } \\
\text { related liabilities); the MRR is in addition to the overall } \\
\text { reserve requirement (RR) of } 17 \text { percent on banks' FX and } \\
\text { kuna liabilities (domestically and from abroad); } \\
\text { Moral suasion: the HNB warned banks on a few occasions } \\
\text { that it would relax or tighten some of its instruments } \\
\text { depending on their foreign borrowing, and issued } \\
\text { guidelines for management of currency induced risks and } \\
\text { credit risk from household lending; } \\
\text { Supervisory and administrative measures to slow down } \\
\text { the pace of rapid credit growth financed largely by bank } \\
\text { borrowing from abroad (e.g., further tightening of the } \\
\text { prudential and supervisory framework; raising risk weights } \\
\text { on unhedged FX linked borrowing; reporting requirements } \\
\text { for unhedged FX loans; FX liquidity requirements and } \\
\text { broadening of their base to include FX-indexed as well as } \\
\text { FX-denominated instruments; and credit controls in the } \\
\text { form of obligatory purchases of low yielding HNB bills for } \\
\text { banks extending excessive credit in } 2003 \text { and end-2006). }\end{array}$ & $\begin{array}{l}\text { - The prudential, supervisory, and administrative measures } \\
\text { (including reserve requirements on bank borrowing) as a whole } \\
\text { aimed at dealing with the external and financial sector } \\
\text { vulnerability implications of the inflows, and have not so far } \\
\text { had a significant impact on bank borrowing or credit growth. } \\
\text { - The preliminary indications suggest that banks are unwilling } \\
\text { to raise their lending rates to offset the rising cost of lending } \\
\text { imposed by these measures so as to keep their market shares. } \\
\text { - While the MRR on banks' external borrowing seems to have } \\
\text { resulted in some scaling down of their borrowing plans after } \\
\text { the rate was raised to 55 percent, an upturn in borrowing has } \\
\text { already been observed, reportedly to comply with the } \\
\text { broadening of the FX liquidity requirements from late } 2006 \text {. } \\
\text { - Banks also evidently seek other ways to overcome the } \\
\text { regulations (e.g., by financing activity through retained } \\
\text { earnings, injection of capital by, or directing clients to, parent } \\
\text { banks, intensifying efforts to attract domestic deposits, etc). } \\
\text { - Moral suasion has had limited effectiveness given the } \\
\text { significant share of foreign banks in the system. } \\
\text { - FX linked lending seems to have slowed down somewhat } \\
\text { recently, reflecting the change in the } 32 \text { percent liquidity } \\
\text { requirement (to broaden its base) as well as higher risk } \\
\text { weights for FX lending to unhedged customers. } \\
\text { - Banks' circumvention efforts led to several attempts by the } \\
\text { HNB to close loopholes by widening the scope of the existing } \\
\text { regulations; a unified nonbank supervisory agency was also } \\
\text { established to strengthen nonbank supervision and thereby } \\
\text { limiting the room for circumvention by switching to borrowing } \\
\text { from nonbank financial institutions. }\end{array}$ \\
\hline \multicolumn{2}{|c|}{ Czech Republic (1993-2004) } \\
\hline $\begin{array}{l}\text { - Large scale sterilization through CNB bills, rising } \\
\text { unremunerated reserve requirements (1994-1997), and } \\
\text { automatic conversion of government privatization revenues at } \\
\text { the CNB. } \\
\text { - Liberalization of capital outflows (1995). } \\
\text { - Administrative measures, such as limits on short-term open } \\
\text { positions with nonresidents and margin fees on FX } \\
\text { transactions with the CNB (1995). } \\
\text { - Greater exchange rate flexibility through a widening of the } \\
\text { exchange rate band (from 0.5 to } 7.5 \text { percent) in early } 1996 \\
\text { followed by a forced exit to a floating regime. } \\
\text { - Interest rate cuts, occasional interventions, and set up of a } \\
\text { government account at the CNB for conversion of privati- } \\
\text { zation proceeds under free float and IT regime after } 1998 \text {. }\end{array}$ & $\begin{array}{l}\text { - Was moderately effective in providing some monetary policy } \\
\text { autonomy under the pegged exchange rate in short-term, but } \\
\text { involved substantial quasi-fiscal and real costs. Overall they } \\
\text { were not helpful in preventing a slower disinflation process. } \\
\text { - Arguably helped reduce net inflows. } \\
\text { - Had only a limited effect in extending the maturity of the } \\
\text { inflows, as they were easily circumvented. } \\
\text { - Temporarily successful in reversing short-term flows in 1996, } \\
\text { providing a greater room for monetary policy maneuvering by } \\
\text { introducing a degree of exchange rate variability. } \\
\text { - Helped reduce the appreciation pressure that was feeding into } \\
\text { undershooting of inflation targets (especially after the 2001-0 } 2 \\
\text { appreciation episode). }\end{array}$ \\
\hline \multicolumn{2}{|c|}{ Estonia (mainly since 2000) } \\
\hline $\begin{array}{l}\text { In responding to the inflows and credit growth financed by them,. } \\
\text { capital or credit controls have been ruled out, given the desire to } \\
\text { avoid policy reversals and inconsistencies with the EU directive, } \\
\text { they were not expected to have an impact in a system dominated } \\
\text { by large conglomerates and foreign banks. CBA ruled out an }\end{array}$ & $\begin{array}{l}\text { Overall, tighter regulatory environment had no noticeable effect } \\
\text { on credit but did increase buffers. Efforts at making households } \\
\text { and banks become more aware of the risks of over borrowing } \\
\text { seem to have started bearing fruit, although it would be hard to } \\
\text { quantify these effects. }\end{array}$ \\
\hline
\end{tabular}




\begin{tabular}{|c|c|}
\hline Policy Responses & Impact \\
\hline $\begin{array}{l}\text { independent interest rate policy. The scope for tighter prudential } \\
\text { limits was also limited by the risk of disintermediation. }\end{array}$ & \\
\hline $\begin{array}{l}\text { - Monetary measures took the form of: delays in the relaxation } \\
\text { of the reserve requirement to the Euro area levels, and } \\
\text { including foreign liabilities in the reserve base on gross basis } \\
\text { while abolishing vault-cash deductibility from the base. } \\
\text { - Fiscal measures: tightening fiscal policy further has been } \\
\text { difficult; the authorities attempted to reduce borrowing } \\
\text { incentives by limiting mortgage interest rate deductibility that } \\
\text { encourages real estate related borrowing. } \\
\text { - Prudential and supervisory measures: Given the limited } \\
\text { monetary tools available and difficulty to influence foreign } \\
\text { bank behavior, the authorities' supervisory effort has been } \\
\text { focused on risks from rapid credit growth, particularly in the } \\
\text { real estate sector. Measures included: maintaining the higher } \\
\text { capital adequacy requirement; increasing risk weightings of } \\
\text { mortgage loans from } 50 \text { percent to } 100 \text { percent (March 2006); } \\
\text { promoting better understanding of risks associated with } \\
\text { excessive credit growth (hence to reduce lending and } \\
\text { borrowing exuberance), especially in the mortgage loan } \\
\text { market; and enhancing cooperation between home/host } \\
\text { supervisors. } \\
\text { - Communication or “moral suasion” tools: the BoE } \\
\text { recommended that the government abolish certain tax relief } \\
\text { and guarantee schemes in the mortgage market so as not to } \\
\text { interfere in market developments; “moral suasion” letters were } \\
\text { sent to banks, their Scandinavian owners, and to respective } \\
\text { regional supervisory authorities. }\end{array}$ & $\begin{array}{l}\text { - Capital inflows and rapid credit growth has continued with a } \\
\text { peak in the annual growth in real sector credit at more than } 50 \% \\
\text { at the end of } 2005 \text {. The measures in the last four years have not } \\
\text { yet had any visible impact to slow down credit growth. } \\
\text { - Government reluctance to make unpopular decisions to abolish } \\
\text { the relevant tax reliefs and existing state guarantee schemes in } \\
\text { the housing loan market has continued to provide incentives for } \\
\text { rapid credit growth. } \\
\text { - The authorities have found that the large presence of foreign } \\
\text { banks with easy access to funds, though beneficial for many } \\
\text { reasons, has limited their ability to influence bank behavior by } \\
\text { regulation. Moral suasion tool has also not been helpful since } \\
\text { foreign banks have paid more attention to instructions from } \\
\text { parents and strong competition has prevented banks from } \\
\text { slowing credit growth so as not to lose market share. }\end{array}$ \\
\hline \multicolumn{2}{|c|}{$\begin{array}{ll} & \text { Hungary (1995-2006) }\end{array}$} \\
\hline $\begin{array}{l}\text { - Large sterilized interventions, when the exchange rate band } \\
\text { was narrow (until 2001). } \\
\text { - Greater exchange rate flexibility through a widening of the } \\
\text { crawling band (from } \pm 2.25 \text { to } \pm 15 \text { percent) in } 2001 \text {, though } \\
\text { intra-marginal interventions provided limited de facto } \\
\text { flexibility. } \\
\text { - Adjustment in exchange rate regime parameters, e.g., by } \\
\text { reducing monthly rates of crawl to slow down the depreciation } \\
\text { of the currency (to accommodate the appreciation pressures). } \\
\text { - Gradual decrease in interest rates permitted by disinflation; } \\
\text { - Cautious liberalization of the capital account (with controls } \\
\text { on certain transactions-e.g., derivative transactions and } \\
\text { lending to nonresidents in domestic currency maintained). } \\
\text { - Debt management tools: Early repayment of foreign public } \\
\text { debt through privatization receipts and shifting the } \\
\text { denomination of the debt in favor of the domestic currency. } \\
\text { - Moral suasion: Possibility to impose measures and controls } \\
\text { against destabilizing capital inflows under extraordinary } \\
\text { circumstances, as well as threats to impose stricter reserve } \\
\text { requirements to stem the inflows and to reduce remuneration } \\
\text { on reserve requirements if banks’ on-balance sheet open } \\
\text { positions exceeded } 30 \text { percent of their capital (never used). } \\
\text { - Strengthening of prudential and reporting environment to } \\
\text { help monitor and manage risks associated with capital flows. } \\
\text { - Risk awareness campaigns by the central bank to warn } \\
\text { against the risks associated with unhedged FX lending of } \\
\text { foreign borrowing by banks to borrowers with limited FX }\end{array}$ & $\begin{array}{l}\text { - Helped address partly the appreciation pressures on the } \\
\text { currency. } \\
\text { - Played a role in limiting speculation against the forint and } \\
\text { potential adverse consequences of a reversal of the interest } \\
\text { sensitive portfolio inflows. } \\
\text { - Helped cope with the implications of the inflows on the } \\
\text { liquidity of the financial system. } \\
\text { - Possibility to impose extraordinary measures could have played } \\
\text { a signaling effect. However, moral suasion in general had } \\
\text { limited effectiveness in an environment of highly integrated } \\
\text { international financial markets and in the presence of large } \\
\text { foreign banks which have easy access to foreign funds and are } \\
\text { supervised and regulated by parent bank supervisors. } \\
\text { - While helpful, the effectiveness may be limited in the absence } \\
\text { of efforts to strengthen cross-border coordination of parent and } \\
\text { host bank supervisors. } \\
\text { - These measures have been aimed not at limiting capital inflows } \\
\text { per se, but at dealing with their implications for facilitating FX } \\
\text { lending; effectiveness of these measures have been likely }\end{array}$ \\
\hline
\end{tabular}




\begin{tabular}{|c|c|}
\hline Policy Responses & Impact \\
\hline earnings and hedging against FX risks. & limited given the persistent strength of FX lending. \\
\hline \multicolumn{2}{|c|}{ Israel (1988-1998) } \\
\hline $\begin{array}{l}\text { - Sterilized interventions to defend the exchange rate band and } \\
\text { prevent excessive appreciation that undermine competitiveness }\end{array}$ & $\begin{array}{l}\text { - Large quasi-fiscal costs that forced seeking other policy options } \\
\text { over time. }\end{array}$ \\
\hline $\begin{array}{l}\text { - Adjustment of exchange rate band parameters and practices } \\
\text { (e.g., abandonment of an 'inner' band and/or adjustment of the } \\
\text { rate of crawl). } \\
\text { - Greater exchange rate flexibility by widening the bands and } \\
\text { introducing asymmetric bands. } \\
\text { - Careful sequencing of capital account liberalization: } \\
\text { - Deferral of further inflow liberalization at times of strong } \\
\text { inflows and liberalization of capital outflows; } \\
\text { - Liberalizing inflows and long-term flows before outflows } \\
\text { and short-term flows, and foreigners' and business sector } \\
\text { flows before domestic and household sector flows; } \\
\text { - Continuous development of domestic money and capital } \\
\text { markets; increased range and sophistication of monetary } \\
\text { operations available; and strengthening bank supervision } \\
\text { and regulation. }\end{array}$ & $\begin{array}{l}\text { - Provided some temporary relief from the impossible trinity } \\
\text { dilemma by introducing more exchange rate flexibility. } \\
\text { - Decisive factor in resolving the holy trinity dilemma by } \\
\text { introducing two-way exchange rate risks. } \\
\text { - Worked well in reducing the market pressure on exchange rate } \\
\text { band limits (thereby also limiting the need to intervene and } \\
\text { sterilize). }\end{array}$ \\
\hline \multicolumn{2}{|c|}{ Latvia (1998-present) } \\
\hline $\begin{array}{l}\text { Monetary measures: Increase in the main refinancing rate on } \\
\text { several occasions to keep rates } 1 \frac{1}{2}-2 \text { percentage points above } \\
\text { ECB rate, phased increase in the reserve requirement ( } 7 / 2004 \text {, } \\
6 / 2005 \text { ) and a broadening in the reserve base to include banks' } \\
\text { foreign liabilities with shorter maturities. }\end{array}$ & $\begin{array}{l}\text { The phased increase in reserve requirements has achieved some } \\
\text { limited success in slowing credit growth, by tightening lats } \\
\text { liquidity conditions which also exerted some temporary upward } \\
\text { pressure on money market rates. Since remuneration rates are } \\
\text { below banks' funding costs, higher and more broadly applicable } \\
\text { reserve requirements acted to raise bank lending rates on both } \\
\text { lats- and euro-denominated loans. In general however, monetary } \\
\text { measures were not sufficient to put persistent downward } \\
\text { pressure on lending growth, which has remained very strong } \\
\text { throughout (2002-2006), though the term structure of banks' } \\
\text { borrowing abroad improved. Reasons for limited effectiveness } \\
\text { include: lack of independent monetary policy; high euroization; } \\
\text { high foreign ownership, and hence unlimited access to funding } \\
\text { sources; and competition and profitability in the banking sector. }\end{array}$ \\
\hline $\begin{array}{l}\text { Prudential and supervisory measures: increase in } \\
\text { supervisory reporting requirements-tightening of onsite/ } \\
\text { offsite inspections, introduction of a rating system for banks, } \\
\text { periodic stress testing activities, increased supervision of } \\
\text { banking groups on a consolidated basis (2004); dialog and } \\
\text { exchange of information between home and host supervisors. } \\
\text { The latter was seen as a way to mitigate the threat to stability } \\
\text { that would arise from a slowdown in capital inflows from the } \\
\text { large foreign banks. Various MoUs have been signed at the } \\
\text { Baltic or bilateral levels. }\end{array}$ & $\begin{array}{l}\text { The immediate impact of these measures have not yet been } \\
\text { observed, with credit growth supported by the inflows having } \\
\text { remained persistent. Regulatory options to contain the buildup } \\
\text { in vulnerabilities have in general been constrained in the EU } \\
\text { context. In a setting where banking services may be offered by } \\
\text { local banks, foreign branches, and cross-border providers, } \\
\text { domestic prudential regulations that are stricter than elsewhere } \\
\text { in the EU have been viewed to be easily evaded by booking } \\
\text { loans offshore. }\end{array}$ \\
\hline $\begin{array}{l}\text { Moral suasion: periodic consultations with individual banks } \\
\text { and bank association; communication of BoL's concerns about } \\
\text { rapid credit growth to banks (through letters to and meetings } \\
\text { with banks) and the media; efforts to raise public awareness } \\
\text { (e.g., through conferences) have been used to raise public } \\
\text { awareness of the risks associated with rapid credit growth and } \\
\text { its associated risks. Administrative controls have not been used } \\
\text { as they were seen as a step backward and a last resort. }\end{array}$ & \\
\hline \multicolumn{2}{|c|}{ Lithuania (mid-late 1990s and 2002-present) } \\
\hline Measures taken to respond to the implications of the inflows for & Credit growth and inflows have remained very strong throughout \\
\hline
\end{tabular}




\begin{tabular}{|l|}
\hline \multicolumn{1}{|c|}{ Policy Responses } \\
\hline the rapid growth of credit, and not to reduce the growth rate per \\
se but to limit the risks involved, including by addressing the \\
factors that may be stimulating credit and excessive risk taking: \\
- Monetary measures: with limited interest rate policy under \\
the CBA, the measures took the form of postponing the \\
planned reduction in reserve requirements to euro zone levels. \\
- Prudential/supervisory measures: tightening of capital \\
adequacy requirements in 2006; continued bank monitoring \\
measures with frequent inspections and ongoing efforts to \\
increase information disclosure under pillar 3 of Basel II; \\
greater cooperation with home supervisors of foreign banks to \\
facilitate supervisory and crisis management cross-border \\
arrangements (agreements concluded with Sweden, Latvia, \\
and Estonia). \\
Moral suasion/risk awareness/market development \\
measures: collection of comprehensive information in the \\
credit registry for risk assessment/management; policies for \\
better understanding of risks; moral suasion letters to banks; \\
public statements on risks related to housing boom; talks with \\
banks and internal ratings based risk assessment measures. \\
Attracting long term investments through improving \\
business and investment climate: Lithuania's relatively low \\
level of FDI and its recent outflow of FDI are causes for \\
concern. Some efforts have been put into improving the \\
investment climate and improving climate for doing business.
\end{tabular}

\section{Poland (1991-2005)}

- Gradual increase in exchange rate flexibility and monetary policy autonomy with an eventual move to a full float (2000) and adoption of inflation targeting (1998).

- Sterilized interventions and tighter monetary policy (OMOs and reserve requirements increased in the second half of the 1990s).

- Administrative measures: The NBP began attracting household deposits directly to drain excess liquidity in the banking system and to encourage banks to adjust deposit rates.

- Liberalization of external trade, including the abolishment of import surcharges and reduction of import tariffs (in connection with the requirements associated with WTO and EU accession), and elimination of a surrender requirement.

- Possibility to impose temporary measures under special circumstances that may threaten monetary/financial stability was put in the Law after OECD related capital account liberalization (e.g., an obligation on residents or nonresidents to maintain noninterest bearing deposits in connection with their capital operations other than FDI, or obligation to resell foreign currency or obtain permit to engage in FX operations).

- Delays in liberalization of the remaining capital controls at times of strong capital inflows and international financial market volatility (second half of the 1990s and early 2000s);

- Mandatory liberalization of outflows (OECD obligations).

- Indirect interventions: Setting up of a government account at the NBP for FX proceeds associated with privatization and Eurobond issues.

\section{Impact}

(2002-2005). Raising foreign direct investment levels-including by attracting foreign investors-will require further improvements in the investment climate.
- Provided time for development of other elements supporting exchange rate flexibility and their sequencing with capital account liberalization and implementation of inflation targeting.

- Full monetary autonomy under a flexible exchange rate and IT finally solved the problem of costly sterilized interventions and economic overheating associated with capital flows earlier.

- Not very effective in curbing domestic demand, as monetary transmission of standard instruments through fragmented and underdeveloped financial markets was limited and higher interest rates continued to attract inflows.

- Improved the CB control over market rates and helped reduce overheating associated with the capital inflows in an environment with weaknesses in monetary transmission.

- Limited growth of FX reserves, also through stimulating imports.

- Never used. (As in the Czech and Hungarian cases, their mere presence could have acted as a deterrent to certain types of crisis prone flows)

- Helped prevent contagion of Asian and Russian crises.

- Possibly contributed to reducing pressure from capital inflows.

- Helped reduce appreciation pressure on the zloty by reducing the net inflow of FX in the market. 


\begin{tabular}{|c|c|}
\hline Policy Responses & Impact \\
\hline $\begin{array}{l}\text { Debt management measures: The authorities shifted from } \\
\text { foreign to domestic borrowing sources; and used part of the } \\
\text { privatization receipts to finance future debt service and buy } \\
\text { back Brady bonds. } \\
\text { - Gradual strengthening of bank regulation and supervision } \\
\text { and development of markets: Prudential regulation and } \\
\text { supervision gradually strengthened up to the level comparable } \\
\text { and in some areas more restrictive than international standards } \\
\text { throughout the 1990s, with tight qualification and provisioning } \\
\text { criteria and limits on open positions since the early 1990s. } \\
\text { - Gradual development of money/FX markets (e.g.derivatives } \\
\text { for hedging) since mid-1990s, supported by a gradual increase } \\
\text { in exchange rate flexibility until 2000. Effective capacity for } \\
\text { monetary operations was also in place since the late 1990s. }\end{array}$ & $\begin{array}{l}\text { - Helped cope with the implications of the inflows on the } \\
\text { liquidity of the financial system. } \\
\text { - Helped improve the resilience of the banking system and } \\
\text { markets to absorb and effectively manage the inflows. }\end{array}$ \\
\hline \multicolumn{2}{|c|}{ Romania (2004-2006) } \\
\hline $\begin{array}{l}\text { - Delays in liberalizing capital controls, including restrictions } \\
\text { on nonresident purchases of government securities and other } \\
\text { controls on short-term capital inflows until } 2005 \text {. } \\
\text { - Allowing exchange rate flexibility (abandoning the crawling } \\
\text { band in November 2004) so as to help reduce the upward } \\
\text { pressure on inflation by allowing the lei to appreciate under the } \\
\text { inflation targeting regime adopted in July 2005); but reduction } \\
\text { in interest rates to discourage capital inflows through partial } \\
\text { sterilization of its interventions. From Late 2005, interventions } \\
\text { were reduced and subsequently abandoned, allowing greater } \\
\text { exchange rate flexibility and tighter monetary policy; the } \\
\text { policy rate was tightened (early 2006), and sterilization } \\
\text { operations intensified to reduce the policy rate gap. } \\
\text { - Improvement in the fiscal balance (fiscal stance of broad } \\
\text { public enterprises tightened relative to GDP). } \\
\text { - Administrative measures: Extending and raising the reserve } \\
\text { requirement on all foreign currency denominated liabilities } \\
\text { successively (2004-06), with a view to curtailing strong } \\
\text { foreign currency lending by the banking system and excessive } \\
\text { lending to unhedged household borrowers; these measures } \\
\text { were combined with the limits on exposures of credit } \\
\text { institutions lending in foreign currency to borrowers without } \\
\text { natural hedging, and refinement of loan classification and } \\
\text { provisioning requirements to take into account FX risks. }\end{array}$ & $\begin{array}{l}\text { - Until } 2005 \text { interest rate sensitive inflows were limited by the } \\
\text { controls on short-term capital inflow, allowing some degree of } \\
\text { monetary autonomy under a de facto crawling band regime. } \\
\text { - The policy remained under pressure from the conflicting } \\
\text { objectives of inflation and competitiveness, which undermined } \\
\text { monetary policy credibility at times: The NBR continued to } \\
\text { intervene in the FX market to prevent lei appreciation and } \\
\text { reduced its sterilization efforts (September 2005); this caused its } \\
\text { effective interest rate (average rate at which it accepts bank } \\
\text { deposits) to diverge from the policy rate (until early 2006), } \\
\text { threatening the fulfillment of its inflation target. } \\
\text { - Reduced the public debt related inflow of capital. } \\
\text { - Strong credit growth, in particular with FX component has } \\
\text { remained persistent throughout 2005-06. Persistent expectations } \\
\text { of exchange rate appreciation continued to feed demand for FX- } \\
\text { denominated loans under an open capital account. The measures } \\
\text { to slow such loans have evidently been followed by banks } \\
\text { raising capital rather than restructuring and reducing their FX- } \\
\text { denominated loans, and engaging in various window-dressing } \\
\text { activities. }\end{array}$ \\
\hline \multicolumn{2}{|c|}{ Turkey (2003-present) } \\
\hline $\begin{array}{l}\text { - Largely sterilized interventions (managing liquidity impacts } \\
\text { of inflows) limiting the extent and speed of nominal } \\
\text { appreciation in 2003-04 period. } \\
\text { - Reduction in interest rates (by more than } 10 \text { basis points } \\
\text { between early } 2004 \text { and early 2005). } \\
\text { - Tighter fiscal policy (in response to overheating and current } \\
\text { account concerns). } \\
\text { - Debt management operations using capital inflows to over- } \\
\text { borrow and move to medium- and long-term domestic } \\
\text { borrowing using local currency instruments. }\end{array}$ & $\begin{array}{l}\text { - Capital inflows have continued to come, with a significant } \\
\text { increase in equity and debt securities, as well as inflows to the } \\
\text { banking system. } \\
\text { - Helped cope with the implications of the inflows on the } \\
\text { liquidity of the financial system. }\end{array}$ \\
\hline
\end{tabular}

Sources: Adahl (2002), Arvai (2005), Enoch and Ötker-Robe (2007), Hilbers, Ötker-Robe, Pazarbasioglu, and Johnsen (2005), Kapteyn, Keller, and McGettigan (2005) in EBS/05/67, Lewis (2005),Kattai and Lewis (2004), Ötker-Robe and Vávra (2007), Schipke, Beddies, George, and Sheridan (2004), IMF Country Reports (various countries and issues), and the national central banks of the countries included in this paper. 


\section{APPENDiX II. EXPERIENCES Of ISRAEL AND POLAND WITH CAPITAL ACCOUNT LIBERALIZATION}

\section{A. Israel: Capital Account Liberalization: Big Bang vs. Gradual Approach}

There have been two major attempts at capital account liberalization in Israel, both of which were followed by episodes of large capital inflows. However, the differences are more illuminating than the similarities: the first experience was ill prepared and had near-ruinous consequences for the economy, while the second one, almost a textbook opposite of the first in both concept and execution, was ultimately successful.

\section{The 1977 Liberalization - A “Big Bang”}

The Current Account of the Balance of Payments had been largely liberalized by the early 1960s, but little progress had been made in opening the Capital Account when, in October 1977 the recently elected government announced a series of dramatic steps, effective immediately (known as the "Ehrlich Liberalization" after the Minister of Finance at the time). These included permitting unrestricted access to foreign credit, allowing foreigners to hold domestic liquid assets, allowing domestic firms to acquire financial assets abroad, and liberalizing rules concerning unilateral transfers abroad. There was also a very large-48 percent_- “one time” devaluation, after which the exchange rate was to be market determined.

The 1977 Liberalization led to extremely large short term capital inflows: in the year following the liberalization, short term capital imports increased by over one billion USD, which at the time was equal to the total amount of domestic demand deposits. In addition to capital inflows, the depreciation contributed to a sharp increase in the money supply through revaluation effects on foreign currency denominated deposits. However, due to a lack of timely data and reporting, these developments were recognized only after a considerable lag. Moreover, the Bank of Israel lacked monetary tools with which it could respond: monetary policy was implemented through high required reserve ratios and quantitative limits on credit aggregates and interest rates. Market based monetary operations and instruments had not yet been introduced.

The effects were not long in coming: inflation almost doubled, to 53 percent in 1978, continued climbing to 137 percent in 1980 and eventually reached hyperinflationary levels by 1985 . In addition, the vast increase in foreign currency denominated borrowing led to large currency exposures in the financial and business sectors, contributing to a major banking crisis in 1983.

Given the lack of policy tools with which to deal with the capital inflows, the response consisted primarily of administrative steps-reinstating capital account controls and restrictions on both inflows and outflows. For example, in February of 1979 the Bank of Israel issued a temporary ban, effective for 60 days, prohibiting Israeli entities from obtaining short or medium term credits in foreign currency. In April the emergency ban was replaced by a system of fines and reserve requirements on foreign currency denominated credits. By the end of 1979 the 
liberalization had been largely rescinded. However, even when controls were reimposed, they proved increasingly ineffective in preventing capital flight on a number of occasions.

In retrospect, it is not difficult to identify the factors which contributed to the failure of the 1977 steps. Almost all the necessary preconditions for success were lacking. Macroeconomic stability was far from secured: prior to the 1977 liberalization inflation was in the vicinity of 28 percent, and the public sector deficit had risen to 16 percent of GDP. When inflation accelerated, there was a lack of suitable policy response, at least partly attributable to a lack of monetary tools available to the Bank of Israel. The domestic money market was undeveloped, segmented, and dominated by government regulation and interference. The financial system lacked the skills and tools to successfully manage the foreign exchange exposures and risks which grew substantially following the opening of the capital account. Moreover, the foreign exchange market was undeveloped, and no mechanism existed for a market determined exchange rate. There were perceptions of an implicit exchange rate guarantee, with the exchange rate determined and managed by the authorities.

\section{The 1988 Liberalization - An Evolutionary Approach}

Almost a decade passed before the next attempt at capital account liberalization, but by then the environment had changed dramatically. A heterodox stabilization program adopted in 1985 had restored macroeconomic stability - the public sector was in surplus, and inflation, while still high at approximately 20 percent annually, was stable. Moreover, the entire approach to liberalization was different: instead of the "big bang' used in 1977, capital account liberalization began anew in 1988 with a policy of extreme gradualism, consisting of literally hundreds of individual steps logically sequenced over more than a decade.

This sequencing of capital account reform was an important element of the response to capital inflows in Israel. Long and medium term capital imports were liberalized first, with short term imports permitted at a later stage. In general, restrictions on inflows were lifted before those on capital outflows. There was also differentiation by sector: liberalization for foreign entities generally preceded that of domestic entities, and amongst the latter, regulations on businesses were liberalized before those for households. The lifting of regulations for institutional investors was usually the most lengthy process.

In addition, the opening of the capital account was accompanied by a gradual approach in other areas of the financial system-liberalizing the capital markets, reducing the role of the government in financial intermediation, developing the foreign currency market, and strengthening the prudential regulation of financial institutions, especially banks. Changes in these areas were sequenced and coordinated to avoid shocks and provide mutual reinforcement. The gradual approach also allowed the consequences of previous steps to be evaluated and appropriate lessons to be drawn, so that future actions could be modified and timed according to actual developments. 
Israel became compliant with the International Monetary Fund's article VIII in 1993. By 1998 most capital controls were lifted, and the regime changed from one where "capital movements are prohibited unless specifically permitted" to one where capital flows were unrestricted unless specifically prohibited. All remaining restrictions were removed at the beginning of 2003, at which time the Controller of Foreign Currency was abolished and the Israeli Shekel became fully convertible.

\section{B. Poland: Three Stages of Capital Account Liberalization}

The first stage of the liberalization process began when Poland launched its exchange rate based stabilization program in 1990. Since the program also aimed at the opening of its economy, it included the adoption of an "internal” convertibility mechanism for a major part of current account (CA) transactions. Thus, initially, it implied full administrative control of capital movements.

It was only in mid-1991 when capital liberalization started, as a result of implementing the Securities and the Foreign Investment Laws, which abolished most restrictions on FDI inflows and liberalized nonresidents' portfolio investment in equity. Another important development was the liberalization of foreign investment in domestic treasury securities (first T-bills, then Tbonds), which took place from 1992 to early 1994. This capital liberalization, conducted by the Ministry of Finance through a series of ordinances, resulted from two main factors: (i) from public sector deficits (5.0 percent of GDP in 1992); and (ii) from a significant decrease in the central bank’s foreign exchange (FX) reserves: in June 1993 they amounted to only USD\$3.5 billion, a level below the value of 3 months of imports.

The second stage commenced with Poland's application for the OECD membership in the fall of 1994. Among others, it required fulfilling obligations resulting from the OECD Codes of Liberalization. Consequently, legislative activity followed. In January 1995 a new FX Law became effective. It not only codified the earlier ordinances liberalizing portfolio inflows but also permitted the selling of Polish securities on international markets (as a result, that year the Ministry of Finance issued its first Eurobonds while Polish companies issued Global Depository Receipts). Despite these provisions, and the expansion of internal convertibility regulations to all CA transactions (which allowed Poland to accept the obligations resulting from IMF's Article VIII in mid-1995), many capital controls remained in place. What is more, they were largely asymmetric, favoring inflows over outflows.

Similarly, as in the first half of the 1990s, further progress was achieved by means of the Ministry of Finance ordinances, which took effect in 1996 and early 1997. The degree of asymmetry was reduced by allowing residents to invest abroad in FDI, real estate, and financial instruments with maturities above 1 year. In certain cases gradually increased ceilings on the volume of some operations leading to capital outflows were applied. Commercial credit activities (resulting in both inward and outward flows) with maturities above 1 year were also liberalized. 
Nevertheless, these regulations fell short of OECD requirements. Eventually, Poland joined the OECD at the end of 1996, being obliged, however, to remove the remaining capital restrictions with the OECD countries by the end of 1999.

During the third stage, capital liberalization had to be continued. In early 1999, a new FX Law became effective. Again, it codified the liberalization decisions introduced earlier by ordinances. It also finally abolished the remaining regulations of the internal convertibility system introduced at the beginning of the decade. Some capital movements liberalization followed (e.g., of selected derivative operations), but restrictions on up to 1 year portfolio and up to 3 months deposit flows were retained with a clear asymmetric bias toward promoting capital inflows and discouraging capital outflows.

Capital liberalization had to be advanced, since one of the cornerstones of the EU is the freedom of capital movements, and by the end of 2002 the European Commission was to publish its opinion on Poland's readiness to join the EU. In April 2000, Poland switched to the floating exchange rate regime, an important precondition for compliance with this requirement. In the fall of 2002, a new FX Law became effective, meeting the requirements of the EU (and OECD) membership. It must be stressed, however, that from a very restrictive, formal point of view, Poland still does not enjoy full capital liberalization as some minor restrictions remain, most importantly on short-term capital flows with the so-called third (i.e. non-EU and non-OECD) countries (Pietrzak 2003, p. 195). 


\section{REFERENCES}

Adahl, M., 2002, "Banking in the Baltics-The Development of the Banking Systems of Estonia, Latvia, and Lithuania since Independence: The Internationalization of Baltic Banking (19982002),” Focus on Transition, 2.

Ariyoshi, A., K. Habermeier, B. Laurens, I. Ötker-Robe, J. I. Canales-Kriljenko, and A. Kirilenko, 2000, Capital Controls: Country Experiences with Their Use and Liberalization, IMF Occasional Paper, No. 190 (Washington: International Monetary Fund).

Arvai, Z., 2005, "Capital Account Liberalization, Capital Flow Patterns, and Policy Responses in the EU’s New Member States,” IMF Working Paper 05/213 (Washington: International Monetary Fund).

Bank of Israel, Annual Report, various years, Bank of Israel, Jerusalem.

Bank of Israel Foreign Currency Department, Annual Report, various years, Bank of Israel, Jerusalem.

Barry, F., Bradley, J., Kejak, M., Vávra, D., 2003, The Czech economic transition: exploring options using a macrosectoral model, Economics of Transition, Vol. 11, September.

Begg, D., 1996, "Monetary Policy in Central and Eastern Europe: Lessons after Half a Decade of Transition,” IMF Working Paper 96/109 (Washington: International Monetary Fund).

Begg, D., 1998, “Pegging Out: Lessons from the Czech Exchange Rate Crisis,” Journal of Comparative Economics 26, 669-690.

Ben-Bassat, A., 1995, “The Inflation Target in Israel: Policy and Development” in Targeting Inflation, ed. Haldane, Bank of England.

Bruno, M., 1997, “Growth, Inflation and Economic Stabilization,” (Hebrew), Bank of Israel, Jerusalem.

Chistensen, J., 2004, “Capital Inflows, Sterilization, and Commercial Bank Speculation: The Case of the Czech Republic in the Mid-1990s,” IMF Working Paper 04/218 (Washington:

International Monetary Fund).

Durjasz P., Kokoszczyński R., 1998 “Financial Inflows to Poland, 1990-96,” Empirica, Vol. 25, pp. 217-42.

EBRD, 2005, European Bank for Reconstruction and Development Transition Report 2005, London, November.

Enoch, C. and I. Ötker-Robe, 2007, Rapid Credit Growth in Central and Eastern Europe: Endless Boom or Early Warning?, Palgrave Macmillan, New York, and International Monetary Fund. 
International Monetary Fund, 2005, Global Financial Stability Report (April).

International Monetary Fund, 2006, “Republic of Latvia: Selected Issues,” IMF Country Report No. 06/354 (October).

International Monetary Fund, 2007, “Republic of Lithuania: Selected Issues,” IMF Country Report No. 07/137 (April).

Gottlieb, D. and Blejer, M., 2001, "Liberalization of the Capital Account of the Balance of Payments,” in The Israeli Economy, 1985-1988, Ben-Bassat et. al., (Hebrew), Am Oved and the Falk Institute for Economic Research, Tel Aviv.

Hersko, S., 2005, "Principle Stages in the Liberalization of Control on Foreign Exchange in Israel 1987-January 2003,” (Hebrew mimeo), Bank of Israel, Foreign Exchange Activity Department (July).

Hilbers, P., I. Ötker-Robe, C. Pazarbasioglu, and G. Johnsen, 2005, Assessing and Managing Rapid Credit Growth and the Role of Supervisory and Prudential Policies, IMF Working Paper 05/151 (Washington: International Monetary Fund).

Hilbers, P., I. Ötker-Robe, and C. Pazarbasioglu, 2007, Assessing and Managing Rapid Credit Growth, in Rapid Credit Growth in Central and Eastern Europe: Endless Boom or Early Warning? Palgrave Macmillan, New York and International Monetary Fund, pp. 84-136.

Hrncir, M., 1998a, Impact of Capital Inflows into the Czech Republic and Policy Responses,” in MacDonald, R. and Cross, R. (eds.) Central Europe towards monetary union: Macroeconomic Underpinnings and Financial Reputation.

Jonas, J. and Mishkin, F., S., 2003, "Inflation Targeting in Transition Countries: Experience and Prospects,” NBER Working Paper, No. 9667.

Kapteyn, A., C. Keller, and D. McGettigan, 2005, "How Should Turkey Respond to Capital Inflows," in "Turkey—Background Studies for the Request for Stand-by Arrangement and Extension of Repurchase Expectations,” EBS/05/67 (April 29).

Kattai, R., and Lewis, J., 2004, "Hooverism, Hyperstabilisation Or Halfway-House? Describing Fiscal Policy in Estonia 1996-2003,” Bank of Estonia Working Paper, 4/2004.

Lewis, J., 2005, "What happened to Fiscal Policy During the EU Accession Process 1996-2004?” mimeo, Bank of Estonia, www.sigov.si/zmar/conference/2005/papers/Lewis.pdf.

Klacek, J., 1997, "Liberalization of Capital Account, Sterilization Policies and Impact on the Exchange Rate: The Czech Case,” Prague Conference: Exchange Rate Policy and Economic Growth in Central and Eastern Europe, ACE RP No. 94-0737, (Prague: CNB). 
Lättemäe, R., 2007, Estonia’s Experience with Rapid Credit Growth,” in Rapid Credit Growth in Central and Eastern Europe: Endless Boom or Early Warning? Palgrave Macmillan, New York and International Monetary Fund, pp. 172,180.

Leiderman, L, 1999, ed., Inflation and Disinflation in Israel, Bank of Israel, Jerusalem.

Leiderman, L. and Bufman, G., 1996, “Searching for Nominal Anchors in Shock-Prone Economies in the 1990s: Inflation Targets and Exchange Rate Bands,” Tel-Aviv University Working Paper 16-96.

Michaeli, M., 2004, “Liberalization of the Foreign Exchange Market in Israel 1950-2002”, in Volume II of Bank of Israel: 50 Years of Striving for Monetary Control, Bank of Israel, Jerusalem.

NBP, 1998, National Bank of Poland Annual Report 1997, Warsaw.

Ozer, B., Reiss, S. and Soffer, Y., 2005, “Israel’s Financial Account Liberalization,” Bank of Israel, Foreign Exchange Activity Department, Jerusalem (August).

OECD, 1996, OECD Economic Surveys: The Czech Republic, p. 40.

Ötker-Robe, I. and D. Vávra, 2007, “Moving to Greater Exchange Rate Flexibility: Operational Aspects Based on Lessons from Detailed Country Experiences,” IMF Occasional Paper 256 (April) (Washington: International Monetary Fund).

Orłowski W.M., 1999, “Makroekonomiczne przyczyny deficytu obrotów bieżących” (Macroeconomic factors behind a current account deficit). In: Bilans płatniczy Polski. Wyzwania i zagrożenia (Poland's balance of payments. Challenges and threats) (edited by U. Płowiec and W.M. Orłowski), Polish Economic Association, Dom Wydawniczy Bellona, Warsaw, pp. 19-35.

Piterman, S. and Topf, B., 1996, “The Key Role of the Exchange Rate Regime,” Central Banking, Vol. VII, No. 3, Winter 1996/7, pp. 67-74.

Polański Z., 2000, "Poland and International Financial Turbulences of the Second Half of the 1990s," In: Financial Turbulence and Capital Markets in Transition Countries (edited by J. Hölscher), London: Macmillan; New York: St Martin’s Press.

Polański Z., 2002, “Promoting Financial Development: Lessons from Poland,” In: Banking and Monetary Policy in Eastern Europe. The First Ten Years (edited by A. Winkler), Palgrave, Houndmills, New York, pp. 104-24.

Polański, Z., 2004 "Poland and the European Union: The Monetary Policy Dimension. Monetary Policy before Poland's Accession to the European Union,” Bank i Kredyt, May, pp. 4-18. 
Ramanauskas, T., 2007, “Assessment of Credit Growth in Lithuania,” in Rapid Credit Growth in Central and Eastern Europe: Endless Boom or Early Warning? Palgrave Macmillan, New York and International Monetary Fund, pp. 190-202.

Pietrzak E., 2003, “Internacjonalizacja systemu finansowego" (Internationalization of the financial system). In: System finansowy w Polsce (Poland’s financial system) (edited by B. Pietrzak, Z. Polański, B. Woźniak), Wydawnictwo Naukowe PWN, Warsaw, pp. 168-96.

Sadowska-Cieślak E., 2003, “Capital account liberalization in Poland,” in: Capital Liberalization in Transition Countries. Lessons from the Past and for the Future (edited by A.F.P. Bakker, B. Chapple), Edward Elgar, UK, Northampton, MA, USA, pp. 225-43.

Schipke, A., C. Beddies, S. M. George, N. Sheridan, 2004, Capital Markets and Financial Intermediation in the Baltics, IMF Occasional Paper 228 (Washington: International Monetary Fund).

Ugolini P., 1996, National Bank of Poland. The Road to Indirect Instruments, IMF Occasional Paper 144, (Washington: International Monetary Fund). 